Was falling inequality in all Latin American countries a data-driven illusion? Income distribution and mobility patterns in Uruguay 2009-2016

Gabriel Burdín Mauricio De Rosa Andrea Vigorito Joan Vilá

ISSN:

ISSN: 
Agradecimientos

Agradecemos a Gustavo González, Fernando Peláez y Sol Mascarenhas, integrantes de la Asesoría Económica de la Dirección General Impositiva durante la realización de este trabajo, por la enorme ayuda brindada a lo largo de esta investigación, sin la cual este estudio no hubiese sido possible. Facundo Alvaredo, Verónica Amarante, Marisa Bucheli, Fernando Esponda, Juan Carlos Gómez Sabaini, Rosa Grosskoff, Juan Pablo Jiménez, Nora Lustig, Jorge Onrubia, Nelson Noya, Darío Rossignolo, Gabriela Pacheco y Alberto Sayagués brindaron valiosos comentarios y sugerencias. Recibimos diversos aportes de los participantes del Taller Desigualdad y Tributación a los Altos Ingresos (CEF-ECLAR AECID; Fiscal Policy and Income Redistribution in Latin America Workshop, CEQ, Tulane University; HLEG OECD Workshop; ECINEQ 2015 y el Seminario Semanal del IECON. El Centro de Estudios Fiscales (CEF) brindó apoyo financiero para una version anterior de este documento que cubrió el período20092012. Todos los errores son de nuestra exclusive responsabilidad.

Forma de citación sugerida para este documento: Burdín G., De Rosa M., Vigorito A. y Vilá J. (2019) "Was falling inequality in all Latin American countries a data-driven illusion? Income distribution and mobility patterns in Uruguay 2009-2016". Serie Documentos de Trabajo, DT 30/2019. Instituto de Economía, Facultad de Ciencias Económicas y Administración, Universidad de la República, Uruguay. 


\title{
Was falling inequality in all Latin American countries a data-driven illusion? Income distribution and mobility patterns in Uruguay 2009-2016
}

\author{
Gabriel Burdín $^{1}$ Mauricio De Rosa ${ }^{* *}$ Andrea Vigorito*** Joan Vilá ${ }^{* * * * *}$
}

\section{Resumen}

Si bien muchos estudios basados en encuestas de hogares indican que en las últimas dos décadas la desigualdad de ingresos disminuyó en la mayoría de los países latinoamericanos, las estimaciones disponibles basadas en registros tributarios para países específicos sugieren que la participación de los grupos de altos ingresos se mantuvo estable o incluso aumentó. Para contribuir al debate actual, proporcionamos evidencia para Uruguay sobre la distribución del ingreso primario entre los perceptores de ingresos en el período 2009-2016 y evaluamos la dinámica del ingreso a lo largo de la distribución. Nuestra investigación se basa en microdatos de encuestas de hogares y un panel de microdatos tributarios de empresas-indivudos concatenados que dan cuenta de alrededor del $75 \%$ de la población adulta. Nuestros hallazgos sugieren que las tendencias de desigualdad son sensibles a la fuente de datos y la medida de desigualdad. Los índices de Gini y Theil antes y después de impuestos disminuyeron, con una caída más leve en los registros de impuestos que en las encuestas de hogares armonizadas. Sin embargo, los patrones de reducción fueron diferentes en los dos conjuntos de datos: mientras que en los registros tributarios los índices sintéticos disminuyeron dentro del 99\% inferior, compensando el aumento de la concentración en la parte superior de la distribución, las estimaciones de las encuestas de hogares indican que la mayor reducción de la desigualdad ocurrió en la parte superior. A su vez, a pesar de caer en encuestas de hogares armonizadas a lo largo de todo el período, las estimaciones basadas en registros impositivos del $1 \%$ superior se mantuvieron estables alrededor del $15 \%$ en 2009-2014, creciendo posteriormente. También investigamos la dinámica de ingresos, mostrando que las posiciones fueron muy estables, con tasas de persistencia promedio cercanas al $80 \%$ en el $1 \%$ superior. Asimismo, encontramos que éstas fueron ligeramente más bajas en el período de disminución de la desigualdad. Finalmente, destacamos que, en el lapso de tiempo considerado, la movilidad del ingreso tuvo un efecto igualador muy modesto.

Palabras clave: ingresos altos, distribución del ingreso, movilidad, tributación a la renta, registros tributarios, Uruguay

Código JEL: D31, H24, O54

\footnotetext{
*LUBS-TheUniversityof Leeds, IZA e IECON, Universidad de la República, Uruguay;

Correo electrónico: gburdin@leeds.ac.uk

**IECON, Universidad de la República, Uruguay, y Paris School of Economics

Correo electrónico:mderosa@iecon.ccee.edu.uy

*** IECON, FCEA, Universidad de la Republica, Uruguay;

Correo electrónico: andrea@iecon.ccee.edu.uy

****IECON, FCEA, Universidad de la Republica:Uruguay;

Correo electrónico: jvila@iecon.ccee.edu.uy
} 


\title{
Was falling inequality in all Latin American countries a data-driven illusion? Income distribution and mobility patterns in Uruguay 2009-2016
}

\author{
Gabriel Burdín * $\quad$ Mauricio De Rosa ${ }^{\dagger} \quad$ Andrea Vigorito Joan Vilá $^{\ddagger}$
}

\begin{abstract}
Although many studies based on household surveys indicate that over the last two decades income inequality decreased in most Latin American countries, income tax records estimations for specific countries suggest that top incomes shares remained steady or even increased. To contribute to the current debate, we provide evidence for Uruguay on primary income distribution among income receivers in the time-span 2009-2016 and assess income dynamics along the income distribution. Our research is based on household surveys micro-data and a unique array of longitudinal matched personal-firm income tax micro-data that covers around $75 \%$ of the adult population. Our findings suggest that inequality trends are sensitive to the data source and inequality measure. Pre and post-tax Gini and Theil indices decreased, with a milder fall in tax records than in harmonized household surveys. However, reduction patterns were different the two data-sets: whereas in tax records synthetic indices fell within the bottom $99 \%$ offsetting increased concentration at the top, household survey estimations indicate that the largest inequality reduction occurred at the top. In turn, while falling in harmonized household surveys throughout the whole period, tax records based estimates of top 1\% income share remained steady around 15\% in 2009-2014 and grew afterwards. We also investigate income dynamics, showing that positions were very stable with average persistence rates at the top $1 \%$ close to $80 \%$. Interestingly, persistence rates were slightly lower in the period of decreasing inequality. Finally, we highlight that, in the time-span considered, income mobility had a very modest equalizing effect.
\end{abstract}

Keywords: top incomes, income inequality, mobility, personal income taxation, tax records, Uruguay. JEL classification: D31, H24, O54

${ }^{*}$ LUBS-The University of Leeds, IZA and IECON, FCEA, Universidad de la República: gburdin@leeds.ac.uk ${ }^{\dagger}$ IECON, FCEA, Universidad de la República and Paris School of Economics: mderosa@iecon.ccee.edu.uy ${ }^{\ddagger}$ IECON, FCEA, Universidad de la República: andrea@iecon.ccee.edu.uy

§IECON, FCEA, Universidad de la República: jvila@iecon.ccee.edu.uy 


\section{Acknowledgements:}

We are grateful to Gustavo González, former coordinator of Asesoría Económica at Dirección General Impositiva, and to his staff, Fernando Peláez and Sol Mascarenhas, for the invaluable help and comments received during this research. Facundo Alvaredo, Verónica Amarante, Marisa Bucheli, Fernando Esponda, Juan Carlos Gómez Sabaini, Rosa Grosskoff, Juan Pablo Jiménez, Nora Lustig, Jorge Onrubia, Nelson Noya, Darío Rossignolo, Gabriela Pacheco, Alberto Sayagues and participants at Taller Desigualdad y Tributación a los Altos Ingresos (CEF-ECLAR AECID); Fiscal Policy and Income Redistribution in Latin America Workshop, CEQ, Tulane University; HLEG OECD Workshop (Berlin); ECINEQ and Instituto de Economia weekly seminar provided valuable comments and suggestions to previous versions of this paper. Centro de Estudios Fiscales (CEF) provided financial support to early versions of this research. All errors remain our own. 


\section{Introduction}

In contrast to the remaining regions of the world, many studies attest that in the first fifteen years of this century, most Latin American countries experienced substantial reductions in monetary poverty and personal income inequality (Lustig et al., 2011, Cornia, 2014, Alvaredo and Gasparini, 2015). Whereas this decline was very fast in 2000-10, it continued at a slower pace in the subsequent five years and, in most cases, came to an end around 2015․ In spite of these recent improvements, income concentration in Latin America is still very high compared to most regions in the world (Alvaredo and Gasparini, 2015) and the interplay among economic growth and redistribution, as well as the paths and public policies needed to promote further redistribution and sustain present achievements are an open academic and public debate.

To date, most research on the recent inequality trends in Latin America has been based on household surveys information, which provides accurate income estimates for low, middle and upper middle income strata but might be subject to underreporting and undercoverage at the top of the distribution Altimir, 1987; Székely and Hilgert, 1999; Cowell and Flachaire, 2015, Bourguignon, 2015, Lustig et al., 2019). In this vein, the findings of the tax-returns based top incomes research (Piketty, 2003, Atkinson et al., 2011) have reinvigorated the discussion on the validity of survey data to provide accurate inequality estimates. Moreover, evidence from personal income tax records for Argentina, Brazil, Chile and Colombia casts doubts on the magnitude of the recent inequality reduction and even over its trend Alvaredo, 2010; Alvaredo and Londoño Velez, 2014, Flores et al. 2019; Morgan, 2017), suggesting that conclusions are very sensitive to the data source, inequality measure, unit of analysis and income definition considered.

Most analysts highlight three main reasons underlying the Latin American inequality fall (with ingredients varying depending on the country): i) a reverse to the mean after the 1980s and 1990s substantial inequality increase; ii) exceptional economic growth rates resulting from the commodity boom and an extremely favourable international context and; iii) a comprehensive package of redistributive reforms (Gasparini et al. 2018). In turn, a worsened international scenario and the absence of deeper reforms to maintain redistribution levels can be associated to the post 2015 evolution. Thus, assessing whether the observed trends are robust to the data-set used in the analysis has relevant implications regarding the debate of the effects which extent economic growth led by the commodity boom and redistributive reforms improved economic and social conditions in the region.

However, reconciling the two strands of the literature to provide a consistent assessment of levels and trends observed in each data source requires accessing to micro-data from household surveys and tax records in order to carry out a careful harmonization process Burkhauser et al. 2012). Because in many schemes tax units are individuals, top incomes studies are not able to reconstruct per capita household income, leaving aside homogamy, fertility differentials and other

\footnotetext{
${ }^{1}$ Tornarolli et al. $(2018)$ identify further equalizing trends in 2014/15 for specific Latin American countries.
} 
relevant features that affect household conformation and might amplify or mitigate primary income inequality. At the same time, in most cases, tax based administrative data lack of information from non taxable income sources, such as non contributory cash transfers and other public benefits. Hence, comparisons among household surveys and tax records based inequality measures are not straightforward.

At the same time, the scholarship on recent inequality trends in Latin America has not addressed how reduced inequality affected persistence rates in the different points of the distribution and the role of income dynamics in improving short, medium and long term inequality. Although recent research for developed countries identifies high persistence levels in the upper tail of the distribution (Aaberge et al., 2013; Auten et al., 2013; Kopczuk et al., 2007; Jenderny, 2016), in the Latin American case, the lack of panel data has hindered the analysis of intra-generational income mobility, particularly in the period of high economic growth rates $\mathrm{L}^{2}$

To contribute to the current debates, this study provides evidence on the evolution of inequality among primary income receivers in Uruguay for 2009-2016. Drawing on the methodology proposed by Atkinson (2007), we compute top income shares estimates and synthetic inequality indices based on tax data and harmonized household surveys and present several robustness checks to support our main conclusions. At the same time, in order to explore the extent and depth of redistribution, we exploit the panel nature of tax micro-data and assess persistence along the income distribution, particularly focusing in top positions.

According to previous studies, the period considered in this research combined a significant inequality decrease from 2008 to 2013 (per capita household income Gini index falling from 0.45 to 0.40$)$, with stability thereafter (De Rosa et al., 2018). Thus, this investigation covers the period of apparently rapid decline in income concentration and its later slowdown.

This study is mainly based on a comprehensive administrative personal income tax microdatabase (Impuesto a la Renta de las Personas Físicas -IRPF- and Impuesto a la Seguridad Social -IASS) matched to the corresponding firms' balance sheets submitted to the tax authorities (Dirección General Impositiva, DGI) for 2009-2016. Since it gathers information from the social security records, these data include the universe of formal workers (despite having earnings below the minimum tax threshold), capital income earners and pensioners and comprises around $75 \%$ of the adult population aged 20 and more. DGI anonymized these data-sets for research purposes. At the same time, we processed micro-data from official household surveys (Encuestas Continuas de Hogares, ECH) gathered by Instituto Nacional de Estadística (INE) to match the full adult population and carry out inequality comparisons.

Since personal income taxation in Uruguay was restored in 2007 (after a 33 years interruption), the use of administrative records for research purposes is very recent. Based on personal income tax records, Burdín et al. (2014a b) and Burdín et al. (2015) analyse a shorter period

\footnotetext{
${ }^{2}$ Due to the lack of suitable data, most studies have been based on household survey pseudo panels or annual official household survey panels.
} 
(2009-2011 and 2009-2012) concluding that although the inequality levels are always higher than in household surveys, trends vary depending on the measure. In this research, we provide estimations for a larger time-span (2009-2016) and also improve significantly the information on capital income by exploiting the newly acquired employers-employees data-base.

This paper contributes to the existing literature in three main avenues. First, we provide further evidence on the evolution of primary income inequality in Latin America among income receivers. Our findings support the hypothesis that there was a decline in income concentration in Uruguay when assessed on the basis of synthetic indices, regardless the data source. However, this fall was milder in tax records compared to harmonized household surveys. Secondly, contrary to the downwards trends depicted by household survey information, we show that tax data reveal that top income shares were stable and started to rise after the inequality reduction period finished. We also conclude that whereas tax records based calculations show an inequality fall of the bottom $99 \%$ offsetting increased concentration at the top throughout the whole period, the larger inequality reduction in household surveys occurred at the top. Thirdly, we provide evidence on intra-generational top income mobility, adding to the emerging literature on this topic. Our estimations clearly convey high persistence rates, with larger values for top fractiles. These results suggest that inequality reduction was not translated into a significant re-ranking among earners. In spite of this, we document that persistence rates were lower in the period of decreasing inequality. At the same time, we show that mobility has a very modest effect on inequality, indicating that annual estimations depict an adequate description of the actual medium term income distribution.

The remainder of this paper is organized as follows. Section 2 reviews previous research on inequality and top incomes shares in Latin America and Uruguay. Section 3 describes the data sources and methods used in this study. Section 4 contains the main results and Section 5 concludes.

\section{Inequality, top incomes shares and mobility patterns in Latin America}

We first present a short overview of international studies assessing the accuracy of household surveys to capture the income sources of interest in this study, focusing on the discussion on top incomes shares estimations and income mobility (2.1). After that, we summarize the existing evidence on top incomes shares in Latin America (2.2) and the recent evolution of inequality in Uruguay (2.3). 


\subsection{Primary income distribution and top income shares}

Considering the caveats of household surveys to capture income from top earners and the short time span they cover, distributional studies have recovered the tradition of analyzing income tax administrative records information (Feenberg and Poterba, 1993; Atkinson, 2007; Atkinson et al. 2011). Thus, the related literature on top incomes has been notably expanded over the last three lustrums (Piketty, 2003; Atkinson et al., 2011; Alvaredo et al., 2013). These studies show that synthetic inequality measures, such as the Gini index, have demonstrated to be sensitive to misreporting problems at the top of the income distribution, even if high income groups represent by definition a very small fraction of the population (Leigh, 2007; Alvaredo, 2011). Furthermore, the underepresentation of richer strata can lead to wrong evaluations of progressivity and redistribution effects of income taxation. In spite of this, Leigh (2007) argues that the top 1\% estimates are a good proxy of Gini indices rankings across countries.

As mentioned in the introduction, due to informational constraints, tax records based studies mainly assess inequality on the basis of individuals and primary income. Depending on the tax regime and the definition of taxable income, in most cases this information does not allow to reconstruct households and to consider the whole set of income sources, which might be the relevant unit for many assessments and, particularly, for public policy design. At the same time, these data are subject to evasion, avoidance and behavioural responses to changes in tax rates. For instance, Feenberg and Poterba (1993) assess the participation of top income groups in the United States based on personal income tax information between 1951 and 1990, showing that the rise in top income shares was partly driven by a substantial reduction in top marginal tax rate from 70 to $28 \%$ implemented in 1986, that impacted evasion rates at the top.

Thus, a bulk of the literature has been trying to create harmonized series to carry out more accurate comparisons among data sources. For instance, Burkhauser et al. (2012) analyze inequality trends in household surveys and personal income tax data for the United States in 1967-2006, previously harmonizing the Current Population Survey to make it consistent with administrative data. They find that once income and tax units are consistently defined across data sources, differences are shortened, even though modifications in the tax system and survey design may explain differential trends in some periods. In order to overcome these caveats, the recent literature has been moving forward to provide a common ground by developing new methods that combine household survey and tax data to ensure that the upper tail is properly captured (Jenkins, 2015; Alvaredo et al., 2016; Piketty et al., 2017; Anand and Segal, 2017; Blanchet et al., 2018). However, to date, there is not a consensus on which is the "benchmark" distribution and there is an ongoing discussion on the appropriate correction methods.

Meanwhile, there are scarce studies assessing top income receivers mobility. The available studies conclude that persistence rates are high in the upper tail of the distribution compared to the remaining income strata (Aaberge et al., 2013; Auten et al., 2013, Kopczuk et al., 2007; Jenderny, 
2016). At the same time, there is also limited evidence on the interplay among inequality and mobility. In the case of Norway, Aaberge et al. (2013) find that augmented top incomes mobility coexisted with increased shares at the top of the distribution.

\subsection{The recent evolution of top income shares in Latin America}

The first attempts to correct household survey income underreporting in Latin America can be traced to Altimir (1987)'s adjustment to national accounts that was included in Economic Commission for Latin America (ECLAC) inequality estimations. However, this methodology has shown to have many caveats (many of them coming from the quality and paucity of national accounts information) and recently ECLAC discontinued this procedure.

Despite the long-standing tradition of distributional studies in Latin America, research focused on top income groups has been less frequent, partly due to scarce data availability, to the weaknesses of income taxation in the region and to the lack of relevant covariates in administrative data. To date, there is available evidence for Argentina (Alvaredo, 2010); Colombia Alvaredo and Londoño Velez, 2014); Brazil (Souza and Medeiros, 2015, Morgan, 2017); Chile (López et al., 2013 Fairfield and Jorratt De Luis, 2016, Flores et al., 2019) and Uruguay (Burdín et al., 2014b, De Rosa and Vilá, 2017). However, many of these studies cover a shorter period than the top incomes scholarship for developed countries and either rely on tabulations for specific years or are based on micro-data that cover tax-payers or the upper income strata.

In regard to the period of recent decline, most top incomes studies conclude that inequality trends vary depending on the data source (Table 1). For instance, Alvaredo and Londoño Velez (2014) find that top income shares in Colombia remained steady (at around 20\%) in the period that household survey-based Gini indices fell (2006-2010), even when corrected for underreporting. In turn, Flores et al. (2019) identifies opposite trends for Chile, with an increase in tax based top incomes shares since 2000. Souza and Medeiros (2015) analyze the case of Brazil during 20062012 using the Blanchet et al. (2018) tax-based correction on household survey data. They report that inequality indices remained stable, with top income shares representing around $25 \%$ of total income throughout the whole period. However, the more striking results come from Morgan (2017), who analyzes a longer span combining household survey and tax information, following the Distributional National Accounts (DINA) guidelines (Alvaredo et al. (2016)). He finds a trend towards increased or steady income concentration in Brazil, contradicting most of the previous research that unanimously identified a consistent and long period of rapid inequality decline from survey data (Lustig et al., 2011; Barros et al., 2006). However, the study also reports a decline in labour income inequality which is consistent with the previous literature and with the income sources mainly captured by household surveys. Since previous studies for Latin American countries were not able to exploit micro-data for a significant fraction of the population, the comparisons that were carried out did not include the calculation of synthetic inequality indices, in tax data. 
Table 1: Top income shares and Gini indices in Latin American countries. Circa 2000-2015

\begin{tabular}{|c|c|c|c|c|}
\hline Country & Year & $\begin{array}{l}\text { Top 1\% share } \\
\text { (primary in- } \\
\text { come) }\end{array}$ & Source & Gini coefficient \\
\hline Argentina & $2001 / 06$ & $14.3 / 16.8 \%$ & Alvaredo $(2010)$ & $0.504 / 0.493$ \\
\hline \multirow[t]{2}{*}{ Brazil } & \multirow{2}{*}{$\begin{array}{l}2001 / 15 \\
2005 / 12\end{array}$} & \multirow{2}{*}{$\begin{array}{l}26.3 / 27.5 \% \\
22.7 / 26.4 \%\end{array}$} & Morgan (2017) & \multirow{2}{*}{$\begin{array}{l}0.583 / 0.513 \\
0.556 / 0.526\end{array}$} \\
\hline & & & $\begin{array}{lr}\text { Souza } & \text { and } \\
\text { Medeiros } & (2015)\end{array}$ & \\
\hline Chile & $2000 / 15$ & $20.2 / 23.7 \%$ & $\begin{array}{lll}\text { Flores et al. } \\
(2019) & & \end{array}$ & $0.526 / 0.448$ \\
\hline Colombia & $2007 / 10$ & $20.7 / 20.4 \%$ & $\begin{array}{ll}\text { Alvaredo } & \text { and } \\
\text { Londoño } & \text { Velez } \\
(2014) & \end{array}$ & $0.59 / 0.554$ \\
\hline
\end{tabular}

Note. The sources for top income share's estimations (primary income) are Alvaredo (2010); Morgan (2017); Souza and Medeiros (2015); Flores et al. (2019); Alvaredo and Londoño Velez (2014). Non of the top income shares depicted were scaled up to National Income. Gini indices based on household surveys are available in SEDLAC (2019), and refer to per capita household income.

Even when tax records are available, identifying correctly capital income can be difficult due to the design of tax systems and particularly the interplay among firm and personal income taxation. For instance, in their study for Chile covering 2005-2009, Fairfield and Jorratt De Luis (2016) and Flores et al. (2019) use information from individuals and firms tax returns and impute accrued profits and accumulated undistributed profits to taxpayers using ownership shares directly estimated from businesses tax-return forms. These studies indicate that although levels are extremely sensitive to this procedure, trends do not vary.

Finally, intra-generational mobility studies for Latin America are also scarce and mostly rely on pseudo -panels. was able to calculate persistence rate for the top fractions of the population. In the context of the top incomes literature, only Cano (2015) was able to calculate persistence rate for the top fractions of the population.

\subsection{Recent inequality trends in Uruguay}

Uruguay is a low inequality country in the Latin American context. However, income concentration started to fall in 2008, after 15 years of stability or concentration, and later than most countries of the region (SEDLAC, 2019; ECLAC, 2019) ${ }^{3}$. In this case, reduced inequality resulted from a combination of outstanding economic growth (led by the commodity boom) and employment

\footnotetext{
${ }^{3}$ In fact, household survey information reveals that the concentration trend that started in 1998 and peaked with the 2002 severe economic crisis still remained until 2008 (Amarante et al. 2014)
} 
rates coupled with a comprehensive package of redistributive reforms promoted after the centreleft coalition Frente Amplio took office in 2005 (see Figures 1 and A.1). Although it is difficult to single out the specific effect of a particular intervention, most studies highlight the key role of increased minimum wages; the restoration of centralized wage-setting mechanisms; a tax reform including the reinception of personal income taxation in 2007 and; a significant expansion of non-contributory cash transfer schemes (Amarante et al., 2014).

Based on data from the universe of personal income tax records, Burdín et al. (2014a b) and Burdín et al. (2015) analyze inequality trends in 2009-2012, concluding that levels are higher than in household surveys, whereas trends vary depending on the inequality measure. While synthetic indices (Gini and Theil) show a decline both in tax records and household surveys, top income shares remained stable in the former while fell in the latter. As trends differ, during the period under study, the gap between ECH and tax records based estimations widened (Burdín et al., 2014b).

Besides expanding the series with five additional years, with respect to Burdín et al. (2014b), we introduced several methodological modifications in the estimations and our final results differ. The two main innovations in this study rely in the of use a different method to include non nominative profits and interests and in using the matched employer-employee/owner data-base to identify undistributed profits that remained in firms.

Figure 1: Gini and Theil indices. Per capita household income, 1986-2016

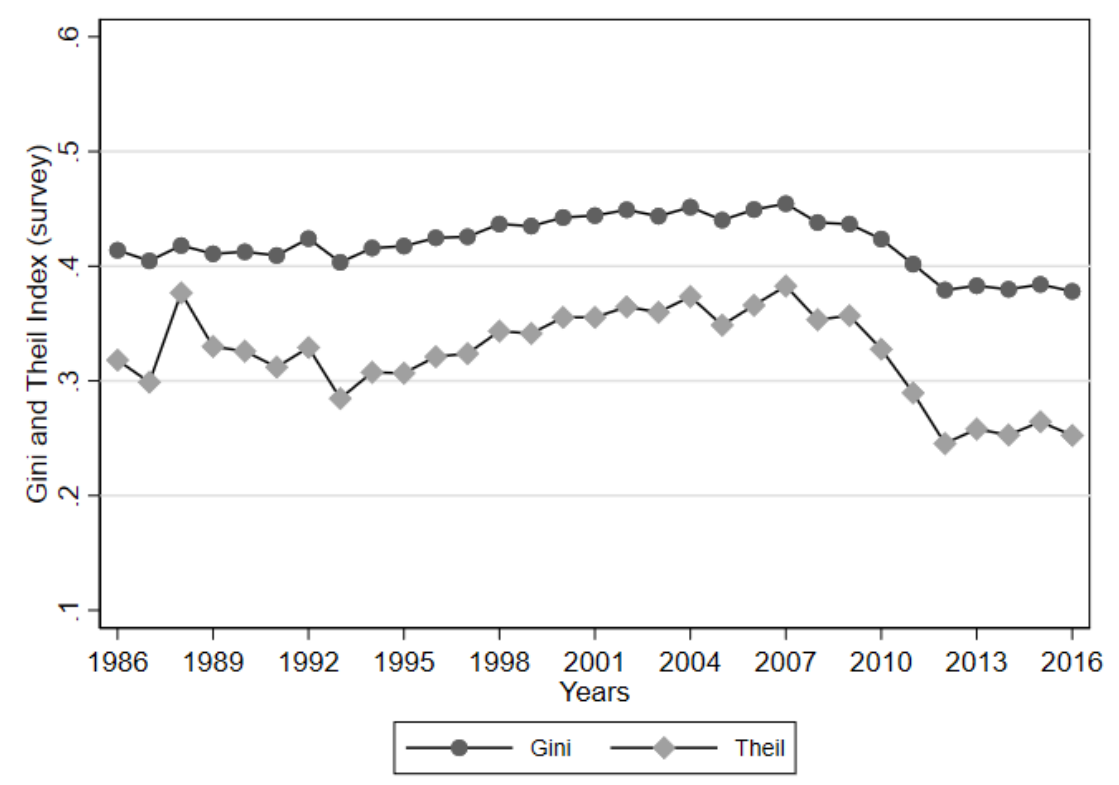

Note. Own calculations based on ECH micro-data. Per-capita household income includes all cash and in-kind income sources and rental imputed income. For a complete description of the household survey, see Section 3 . 


\section{Data and methodology}

We first describe the main features of the data-bases used in this research (3.1.1) and then present the methods implemented to estimate top incomes shares and the remaining inequality measures (3.2). Finally, we turn to the assumptions and procedures underlying the mobility analysis (3.3).

\subsection{Data}

\subsubsection{Income tax micro-data}

The Uruguayan tax system is mainly based on indirect taxes, which roughly represent $65 \%$ of total fiscal revenue. Personal income tax was originally established in 1961 but, jointly with inheritance taxation, was abolished in 1974 by the de facto regime that ruled Uruguay during 1973-1985. Framed in an overarching tax reform, a new and more comprehensive personal income scheme was passed in 2006. The reform introduced a dual personal income tax (Impuesto a la Renta de las Personas Físicas, IRPF), combining a progressive tax schedule on labour income and pensions with a flat tax rate on capital income and a corporate income tax (Impuesto a la Renta de las Actividades Económicas, IRAE). 出

Details on tax rates for the three taxable income sources can be found in Tables A.1, A.2 and A.3. Although tax units are individuals, married couples can fill a joint labour income tax return. In practice, only $1.8 \%$ of the taxpayers choose this regime. Table A.4 depicts average income for different fractiles in Uruguayan pesos. In most brackets, a substantial increase in current and real incomes can be noticed. The tax schedule remained unchanged in the period, with the exception of a relatively small tax increase for top income brackets in 2012.5

DGI created anonymized databases for research purposes that put together two administrative data sources: (a) the universe of IRPF and IASS tax payers for 2009-2016, which include in detail information on capital, pension, labour income for each occupation, tax burden and deductions (Table A.5); (b) the universe of labour income and pensions from social security records (provided by the Social Security Institute, Banco de Previsión Social, BPS) for formal workers and pensioners. As BPS acts as the retention agent for all individuals, the information on labour earnings and pensions included in the micro-data comprises pensioners and the universe of workers contributing to the social security, despite being net tax payers or not. Additionally, each record contains information on sex, age, industry, and whether the individual is a salaried worker or selfemployed. Additionally, DGI provided a supplementary database with information on income and

\footnotetext{
${ }^{4}$ Although pensions were originally included in IRPF, soon after the reform this component was declared unconstitutional. As a result, pensions were no longer taxed by IRPF; instead, a new progressive tax on pensions with similar characteristics was passed in July 2008, known as Impuesto de Asistencia a la Seguridad Social (IASS).

${ }^{5}$ Recent evidence suggests that this change did not result in a reduction of reported income after the reform, and, therefore, it did not affect top income shares estimations, although it may have had minor impact on income composition for some groups of taxpayers, (Bergolo et al., 2019).
} 
taxes of those personal services societies that chose to pay corporate income tax (IRAE) instead of IRPF (see row IRAE in Table A.5). This option is available for liberal professionals and, thus, these earnings can be assimilated either to mixed or labour income. The resulting micro-database covers $75 \%$ of the population aged 20 years and more

We grouped capital income in the following categories: profits and dividends; housing rents; interests from bank deposits and; other capital income. As most top incomes studies, we excluded capital gains. Due to the bank secrecy act and to previous regulations that allowed firms to issue bearer shares, we did not access to micro-data on interests and non nominative profits.

From Table A.6 it can be noticed that while the first is not a relevant concern, non nominative profits account for a half of total profits.7 Since we lacked information on the characteristics of non nominative profits receivers, to assign the total amount among individuals in the tax-records micro-data, we distributed it proportionally to total capital income held by the corresponding individua 8

It is noteworthy that until 2016, firms were allowed to keep undistributed profits without any time limit. Thus, instead of declaring formal profit withdrawals (taxed at a $7 \%$ personal income rate additional to the $25 \%$ rate on corporate income), many firm owners took cash advances. Thus, our estimations convey a surprisingly low number of profit withdrawals per year (less than 10\% of the firms distributed benefits) and this is partly explained by payments in advance representing a large proportion of distributed profits. Since these payments are singled out in the firms balance sheets data-base, we were able to partially reconstruct the actual distribution of capital income had these payments in advance been declared as distributed profits.

Corporate tax declarations and balances are available for the sub-set of firms with revenues above $40.000 \mathrm{U} \$ S$ a month, that are obliged to present annual balances to DGI (around $60 \%$ of registered firms). For this subset, we were able to match individuals appearing in the tax records micro-data to the balances of the firms they are related to (either being employees or owners). In this way, it is possible to compute accrued, reinvested, undistributed and distributed profits for each firm and fiscal year.9

We first computed the amount of undistributed profits for each year. Secondly, based on the balance line indicating "share-holders/owners withdrawals in advance", we estimated the potentially undistributed profits and checked whether the firm also distributed profits during the same

\footnotetext{
${ }^{6}$ The remaining $25 \%$ is composed by informal workers $(38,9 \%)$, unemployed $(10,9 \%)$ and individuals out of the labour force not receiving pensions or capital income $(50.2 \%)$.

${ }^{7}$ In recent years, to comply with the international regulations set by the Basel agreement, Uruguay restricted the issuance of bearer shares. In spite of this policy change, the percentage of non nominative profits looks steady in the period under analysis. Thus, potential trespassing from non nominative to nominative profits does not seem to be a relevant concern.

${ }^{8}$ As shown by De Rosa et al. (2018), there are very few firms that distribute profits in Uruguay, to a relatively limited number of individuals. Therefore, imputing non nominative profits only to nominative profits receivers, is likely to overestimate the concentration of capital incomes. By distributing it proportional to total capital income, the capital income distribution remains unchanged.

${ }^{9}$ In Uruguay the fiscal year corresponds to the calendar year.
} 
year or the next. If the firm had a positive value in the "potentially undistributed profits" line and in the next year profits were distributed and these accounts fell to zero, we only considered the actual distributed profits.

Since we lacked information allowing to identify business owners or share-holders and we could only label as such to those individuals withdrawing profits, we assigned the "potential profits withdrawals" amounts based on three different assumptions. In the first one, we distributed these additional profits among all the individuals we could identify as firm owners based on different years withdrawals. In those cases in which we did not have this information, we created new individuals. Secondly, we distributed profit withdrawals among top labour income earners in the corresponding firm. Third, we combined the two previous criteria and created additional individuals in case the firm reported workers and profit withdrawals in the time span considered in this study. The three criteria yield to the same results, so we stick to the last one. The final number of newly created individuals was between 0,09 and $0,11 \%$ depending on the year (see Table A.7.).

As it is the case of most top incomes research, besides the standard limitations of tax data, a relevant caveat of this study comes from the fact that in Uruguay, tax units are individuals and we cannot observe how their income is combined in households. Because they are not comprised in the taxable income definition, we are also not considering relevant income sources such as the value of owner-occupied housing and private and non-contributory public transfers ${ }^{10}$.

\subsubsection{The Uruguayan household surveys}

The National Statistical Office (INE) gathers household surveys (Encuestas Continuas de Hogares, $\mathrm{ECH}$ ) since 1968. At present, ECHs are nationally representative and are carried out throughout the whole year. They collect information in detail on household composition, labour force status and outcomes, socioeconomic variables and personal income by source. Further methodological details can be found in INE (2019).11.

After-tax labour income is gathered for each household member aged 14 years or more, including cash and in-kind payments for salaried workers, self-employed and business owner (separately recording the main occupation and the remaining ones). The reporting period corresponds to the month previous to the interview. The survey also gathers information on the contributory status of the labour force in each occupation.

Except for profit withdrawals by the self-employed and business owners, capital income is captured in the household questionnaire, which implies that each item is added up for the

\footnotetext{
${ }^{10}$ Many studies indicate that both factors are relevant in Latin America, but with a greater role of the latter to explain the recent reduction of inequality (Lustig et al., 2011, Cornia, 2014, Alvaredo and Gasparini, 2015). Moreover, in the case of Uruguay, household survey based studies conclude that the static contribution of child benefits and other cash transfers is similar to the equalizing effect of the income tax (Bucheli et al., 2013, Amarante et al. 2014).

${ }^{11}$ Sample size was 46,550 households and 120,781 individuals in 2009 and 46,669 households and 128,204 in 2016.
} 
whole household and attributed to the household head. The questionnaire also gathers interests, dividends, rents, benefits and imputed value of owner occupied housing. Capital income sources are reported on an annual basis; only imputed value of owner occupied housing is gathered for the month previous to interview.

Transfer income is separately collected for each individual and origin (public/private, domestic/remittances), including pensions (retirement and survival), child allowances, unemployment insurance, accident compensation and other non contributory benefits.

As in the rest of the world, the accuracy of household surveys has been a longstanding discussion in Latin America (Altimir, 1987, Székely and Hilgert, 1999). In the same vein, during the 1990 decade, several studies analyzed the accuracy of ECH to capture household income by source compared to National Accounts and expenditure surveys (Groskoff, 1992; Mendive and Fuentes, 1996, Amarante and Carella, 1997). More recently, Amarante et al. (2007) find that ECH captures $39.7 \%$ and $23 \%$ of the total amount of housing rents and interests on bank deposits. Based on a subsample of households with children aged 0 to 3 that gathered ID numbers and was merged to tax records, Higgins et al. (2018) find the expected misreporting pattern: overreporting in ECH below the median and underreporting thereafter. At the top $1 \%$ ECH captures $56 \%$ of DGI income.

In order to harmonize ECH information with the income tax micro-data, we computed income for formal workers, pensioners and capital earners on an individual basis and restricted income sources to the ones captured by DGI micro-data according to the taxable income definition (see Burdín et al. (2014b) for details).

\subsection{Top income shares estimation: population and income controls}

In order to estimate top income shares, we first computed income and population control totals following the methodology developed by Atkinson (2007). Although the standard practice in most top income studies is departing from National Accounts System (NAS) information Atkinson, 2007 Atkinson et al., 2011), in Uruguay the last official estimation of the households income account is available for 1997. Thus, to estimate the income control we compute total income captured in tax records and add up an estimation of informal earnings by restricting ECH microdata to individuals aged 20 or more (more on this below) that were not contributing to the social security and were not receiving pensions or capital income. 12 Tax records income represents around $50 \%$ of annual GDP, whereas ECH informal earnings account for 3\% (Table 2). As a whole, the participation of the aggregate income control grows throughout the whole period. However, it is worth noticing that it never reaches $70 \%$, which is the standard figure found in top incomes

\footnotetext{
${ }_{12}$ Burdín et al. (2014b) compared the procedure used in this study to the variant that starts from NAS, reconstructing the households income account based on several assumptions. Since the two options yielded to very similar results, we stick to the first method.
} 
studies for developed countries.

In turn, computing the population control requires the definition of a reference population, since tax micro-data represent formal workers, capital income earners and pensioners. The standard practice in top incomes research is to consider the population projections of individuals aged 15 or 20 years and more. Since most top incomes studies for Latin America consider the latter, we stick to this criterion, as long as the number of individuals in DGI micro-data under that age is really low.

As a whole, Uruguayan tax records account for around $75 \%$ of the population aged 20 or more (Table 3).$^{13}$ As mentioned in the previous paragraphs, to account for total income, we added the sub-set of ECH individuals aged 20 or more with zero or informal earnings to DGI micro-data. As it can be noticed by adding the second and fourth columns of Table 3 , this value is above the total population (first column). Thus, we compressed the ECH population weight to fit the Population Projections using the factors displayed in the last column. This procedure presents a caveat since it assumes that individuals cannot simultaneously receive formal and informal income. The findings by Higgins et al. (2018) suggest that a significant fraction of low income population combine the two types of income. Though, we might be overweighting the lower tail of DGI.

Table 2: Income control

\begin{tabular}{l|cccccccc}
\hline & 2009 & 2010 & 2011 & 2012 & 2013 & 2014 & 2015 & 2016 \\
\hline Tax records & 13,613 & 17,486 & 21,205 & 23,841 & 27,474 & 28,227 & 26,932 & 27,775 \\
ECH & 1,009 & 1,297 & 1,478 & 1,470 & 1,497 & 1,304 & 1,267 & 1,296 \\
Total & 14,623 & 18,783 & 22,684 & 25,311 & 28,971 & 29,531 & 28,199 & 29,071 \\
GDP & 31,661 & 40,284 & 47,962 & 51,265 & 57,531 & 57,235 & 53,274 & 52,687 \\
\hline Tax records/GDP & $43.0 \%$ & $43.4 \%$ & $44.2 \%$ & $46.5 \%$ & $47.8 \%$ & $49.3 \%$ & $50.6 \%$ & $52.7 \%$ \\
ECH/GDP & $3.2 \%$ & $3.2 \%$ & $3.1 \%$ & $2.9 \%$ & $2.6 \%$ & $2.3 \%$ & $2.4 \%$ & $2.5 \%$ \\
Total/GDP & $46.2 \%$ & $46.6 \%$ & $47.3 \%$ & $49.4 \%$ & $50.4 \%$ & $51.6 \%$ & $52.9 \%$ & $55.2 \%$ \\
\hline
\end{tabular}

Note. Own calculation based on tax records (DGI), household surveys (ECH) and GDP from Uruguay's National Accounts. GDP in millions of Uruguayan pesos (current). $1 \mathrm{U} \$ \mathrm{~S}$ was equivalent to 20-23 Uruguayan pesos in the reference period.

\footnotetext{
${ }^{13}$ One of the facts explaining the broad coverage of the adult population of the data base used in this study derives from the fact that informality rates in Uruguay are lower than in most Latin American countries. Since 2006, there was also an explicit policy promoting formalization: whereas in 2009 social security coverage rates were $67.8 \%$ of total workers and $80.6 \%$ among salaried workers, in 2016 these figures rose to $74.7 \%$ and $87.9 \%$ respectively. Although in Uruguay there is a family tax return option available, $98.5 \%$ of the individuals in our data-base choose the individual regime.
} 
Table 3: Population control

\begin{tabular}{lcccccc}
\hline & Total population & Tax records & Tax record (\%) & Survey population & Tax record + survey & Survey adjust (\%) \\
\hline 2009 & $2,348,300$ & $1,721,207$ & 73.3 & 760,720 & $2,481,927$ & 82.4 \\
2010 & $2,370,788$ & $1,722,902$ & 72.7 & 743,279 & $2,466,181$ & 87.2 \\
2011 & $2,390,888$ & $1,758,779$ & 73.6 & 697,776 & $2,456,555$ & 90.6 \\
2012 & $2,410,258$ & $1,793,012$ & 74.4 & 687,845 & $2,480,857$ & 89.7 \\
2013 & $2,430,379$ & $1,852,341$ & 76.2 & 686,487 & $2,538,828$ & 84.2 \\
2014 & $2,451,739$ & $1,928,833$ & 78.7 & 676,524 & $2,605,357$ & 77.3 \\
2015 & $2,474,284$ & $1,916,230$ & 77.4 & 692,600 & $2,608,830$ & 80.6 \\
2016 & $2,497,361$ & $1,923,850$ & 77.0 & 710,096 & $2,633,946$ & 80.8 \\
\hline
\end{tabular}

Note. Own calculations based on population projections (CELADE-INE, 2016), tax records (DGI) and household surveys (INE). Second and third columns depict total number of adults in the tax records, both in absolute terms and as percentage of total adult population. Fourth and fifth columns depict informal and zero-income adult population in the survey and added to the tax data. The last column shows the adjustment to the survey data necessary to match the total control population.

Based on DGI micro-data, population and income controls on one side and harmonized ECHs on the other, we computed pre and post tax top income shares, synthetic inequality indices (Gini and Theil) and the corresponding group and income source decompositions (Shorrocks, 1981, 1999; Lerman and Yitzhaki, 1985). Confidence intervals were calculated by boostrapping (100 repetitions).

\subsection{Mobility analysis}

We exploited the longitudinal nature of DGI data to analyze persistence in individual positions along the income distribution, particularly focusing on top income holders. To implement this analysis we restricted the data-base to the balanced panel.

We first estimated average absolute and positional persistence rates. Both estimates arise from implementing a regression such as the following:

$$
y_{t, i}=\alpha+\beta y_{t-x, i}+\epsilon_{i}
$$

In the estimates of absolute persistence, $y_{t i}$ corresponds to the final logarithm of total income and $y_{t-x i}$ represents the same variable $x$ years before. In the base estimates, the years considered are 2016 against 2009. In the case of positional mobility, a similar procedure is carried out but $y_{t i}$ and $y_{t-x i}$ represents the final and initial rankings. These exercises were also performed splitting the data by sub-period and gender.

In order to assess positional mobility we also built transition matrices, since this conventional and intuitive method allows to observe individuals' movements across different positions in the income distribution between two time points. Following Fields and Ok (1999), the transition 
matrix induced by transformation $x \rightarrow y$ is defined as the matrix $P(x, y)=\left[p_{r s}(x, y)\right] \in R_{+}^{m x m}$, where $m$ are the specified income groups and $p$ is the fraction of individuals belonging to class $r$ in the distribution $x$ and experiencing a transition to class $s$. By construction, $\sum_{s=1}^{m} p_{r s}(x, y)=1$ for all $r$.

Finally, we assessed the distributional effect of income mobility by computing top income shares and inequality measures based on annual income and each individuals longitudinallyaveraged income. The difference between these two measures is usually interpreted as the redistributive effect of income mobility on longer-term income (Shorrocks, 1978, 1981).

\section{Results}

We first analyze the evolution of income inequality in Uruguay, assessing trends both in synthetic indices and top income shares. After that, we exploit the longitudinal nature of DGI data and study the persistence rates of individuals in their original positions across the income distribution.

\subsection{The recent evolution of income inequality and top income shares in Uruguay}

\subsubsection{Synthetic inequality indices}

Figure 2 depicts synthetic Gini indices computed on the basis of different ECH and DGI micro-data income aggregates. The longest line is ECH per capita household income, which corresponds to the variable used in most inequality studies. Its evolution indicates a sharp decline between 2008 and 2013 and stability thereafter. Although at higher levels, inequality among income receivers in ECH mimics the path of household income distribution, either considering the original version or harmonized data. In the three options, comparing 2009 to 2013 and 2016 yields to statistically significant differences 14 .

\footnotetext{
${ }^{14}$ See confidence intervals in Table A.8
} 
Figure 2: Gini index by income definition and source, 2004-2016

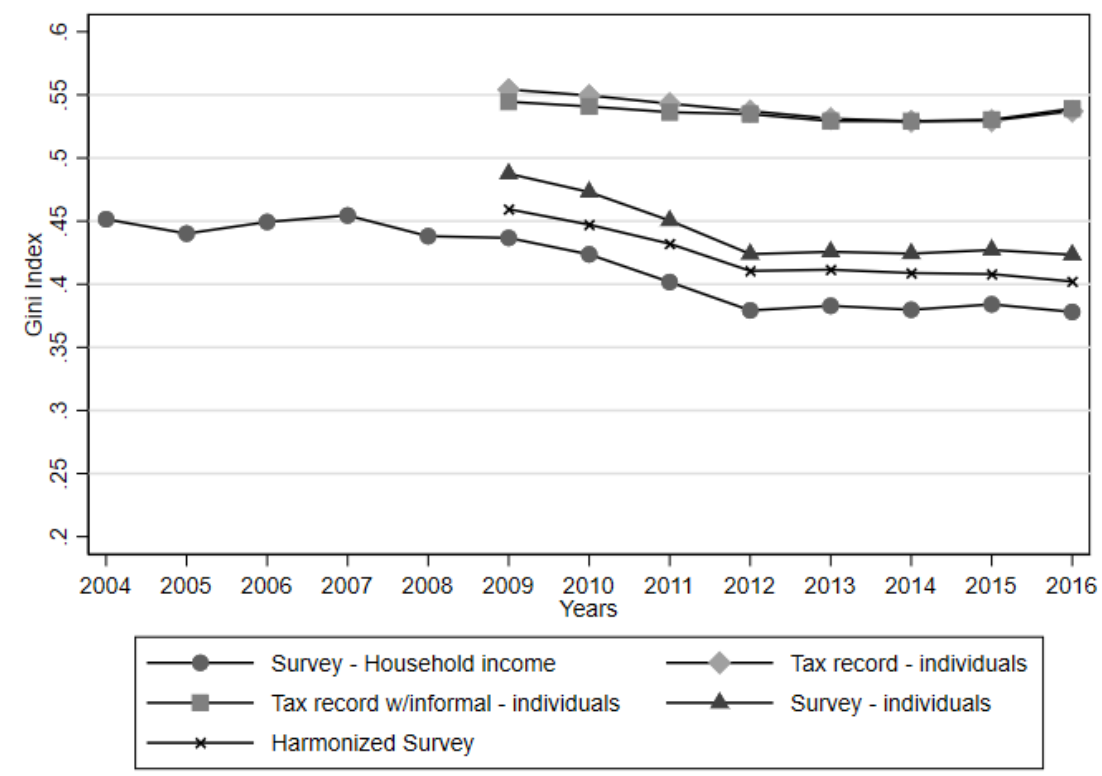

Note. Own elaboration based on household surveys (ECH) and tax records (DGI). In ascending order, the different income aggregates depicted include: (1) ECH per capita household income; (2) harmonized ECH (only formal income receivers, pre-tax earnings) and (3) ECH-formal and informal income receivers; (4) DGI income adding (weighted) ECH informal workers; (5) DGI income.

In turn, DGI micro-data based calculations are presented in two options. In the first case we consider the original information at the tax-records database and in the second one we depict the control income variable (by adding reweighted informal workers and non earners micro-data from ECH). The two lines exhibit a mild decline, with inequality indices converging since 2012 and slightly increasing by 2016. Again, 2009/2016 and 2009/2013 differences are statistically significant.15

Thus, the five income variables confirm an equalising trend comparing 2009 to 2016 and throughout 2009-2013, indicating that these two findings are robust to the data base and harmonization criteria, even when levels are considerably higher in DGI data and the slope of the decline is significantly smaller. Table A.9 suggests that synthetic indices that weight differently the varied points of the income distribution also show a consistent reduction pattern, despite the data-source. Considering the whole period under study, ECH depicts a $25 \%$ inequality reduction, that rises to $42 \%$ for 2009-2013. Since decreasing rates were milder in DGI, the gap among the two sources widened in the last years. Meanwhile, discrepancies arise in the last period (2013-2016). Whereas household surveys estimations still indicate a slight decline in 2013-16, differences are not statistically significant in tax records data.

To conclude this sub-section, we briefly analyze the progressivity and redistributive effects

\footnotetext{
${ }^{15}$ These results also hold when considering only the original DGI data with no further imputations on undistributed and non nominative profits.
} 
of personal income taxation (Table 4). Kakwani indices show that income taxation is progressive in the two data sources. However, levels are almost $20 \%$ higher in ECH, although in 2016 the two indices are very similar. This convergence results from the fact that DGI data show a smooth decreasing trend in tax progressivity throughout the whole period (13\% fall in 2009-2016), whereas ECH values were almost steady and plummeted at the end.

Meanwhile, the comparison of before and after tax Gini indices (Reynolds-Smolensky coefficient), indicate a constant redistributive capacity of 2 percent points in the two data sources. Thus, the proportional redistributive effect in ECH is considerably higher than in DGI. However, Theil index presents a similar reduction in proportional terms in the two data sources (Table A.9.

It is worth noting that although personal income taxation is progressive, its redistributive effect is modest due to low effective rates (5 to $6 \%$ in average with a slight increase throughout the period in two data sources). The latter relates to the dual personal income scheme, the low proportion of taxpayers (see section 3) and the low value of the highest marginal tax rates even for Latin American standards (25\% in 2009-2011 and rose to 30\% in 2012). For instance, OECD top rates are in average $41.5 \%$ (Joumard et al., 2013).

Table 4: Tax progressivity and income redistribution indices, 2009-2016

\begin{tabular}{cl|cccccccc}
\hline & Year & 2009 & 2010 & 2011 & 2012 & 2013 & 2014 & 2015 & 2016 \\
\hline \multirow{5}{*}{ Tax records } & Pre-tax & 0.574 & 0.570 & 0.565 & 0.561 & 0.554 & 0.552 & 0.552 & 0.560 \\
& Post-tax & 0.554 & 0.550 & 0.543 & 0.537 & 0.531 & 0.529 & 0.530 & 0.537 \\
& R-S & 0.020 & 0.021 & 0.022 & 0.024 & 0.023 & 0.023 & 0.023 & 0.023 \\
& Average tax rate & $5.0 \%$ & $5.4 \%$ & $5.4 \%$ & $5.6 \%$ & $5.7 \%$ & $6.0 \%$ & $6.0 \%$ & $6.1 \%$ \\
& Kakwani & 0.334 & 0.331 & 0.334 & 0.327 & 0.328 & 0.324 & 0.301 & 0.293 \\
\hline \multirow{5}{*}{ Harmonized survey } & Pre-tax & 0.481 & 0.468 & 0.452 & 0.430 & 0.432 & 0.429 & 0.429 & 0.423 \\
& Post-tax & 0.459 & 0.447 & 0.432 & 0.411 & 0.412 & 0.409 & 0.408 & 0.402 \\
& R-S & 0.021 & 0.020 & 0.020 & 0.019 & 0.020 & 0.021 & 0.021 & 0.021 \\
& Average tax rate & $5.1 \%$ & $4.8 \%$ & $4.6 \%$ & $4.6 \%$ & $5.0 \%$ & $5.2 \%$ & $5.3 \%$ & $5.1 \%$ \\
& Kakwani & 0.399 & 0.406 & 0.406 & 0.392 & 0.39 & 0.381 & 0.382 & 0.304 \\
\hline
\end{tabular}

Note. Own calculations based on tax records (DGI) and household surveys (ECH). First two rows of each panel (tax records and harmonized survey) depict pre and post-tax Gini coefficient. The remaining rows depict standard tax progressivity indices.

\subsubsection{Top incomes shares}

The three panels in Figure 3 depict the evolution of the top 10, 1 and $0.1 \%$ income shares. Although the point evolution of the top $10 \%$ is very similar to the path described by inequality indices previously presented, confidence intervals rule out the decline hypothesis indicating stability throughout the whole period. Meanwhile, the top 0.1 and $1 \%$ clearly remained almost unchanged in 2009-2013 and exhibit an increase since 2014, although not statistically significant either. 
Figure 3: Top income shares, 2009-2016

(a) Top $10 \%$

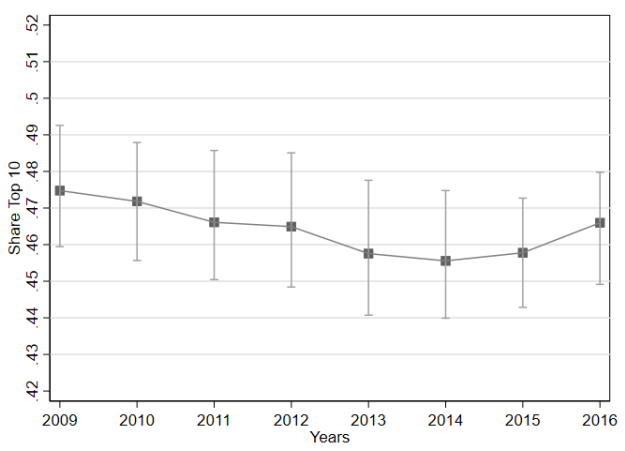

(b) Top $1 \%$

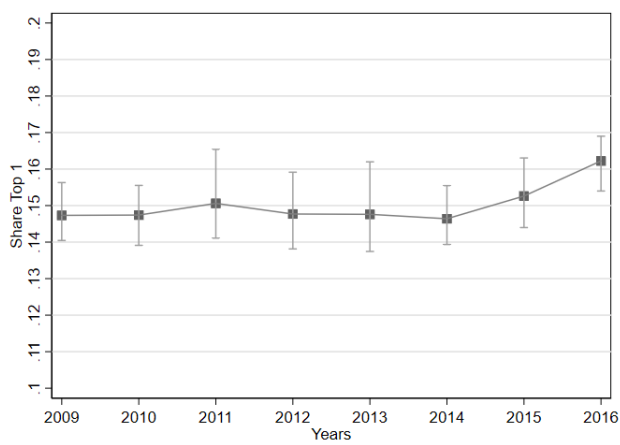

(c) Top $0.1 \%$

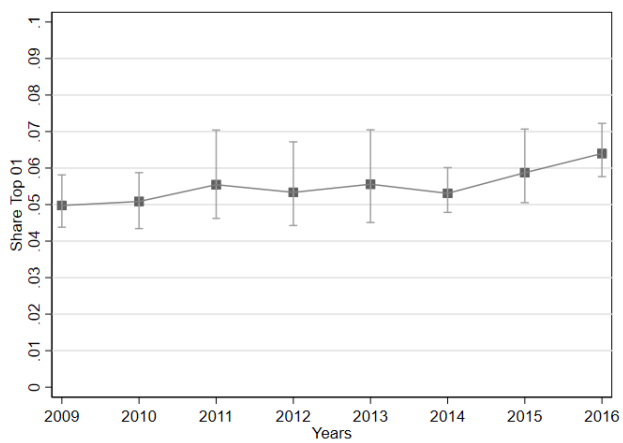

Note. Own calculations based on tax records (DGI) and household surveys (ECH). See point estimates in Table 5

Meanwhile, the shares of the bottom and middle income strata present a mild increase (Table 5). Notice that the top $1 \%$ holds a larger proportion of total income than the bottom $50 \%$ and this gap increased throughout the whole period. A similar comment applies to the middle $40 \%$ respect to the top 10\%, but in this case the gap was narrowed.

Considering the whole period, the point estimate of the top $1 \%$ share moved from 14.5 to 16\%. These values place Uruguay among the countries with the highest concentration at the top in the World Inequality Database, being below the remaining Latin American countries, South Africa and the United States (WID, 2019). It is noteworthy pointing out that this result is partly driven by the bias towards developed countries of WID, resulting from the availability of tax records information across the world.16

As in the case of the Gini and Theil indices, personal income taxation had a constant effect throughout the period, reducing the top 10 and 1\% shares in approximately 2.5 and 2 percent points respectively, with the subsequent increase at the middle $40 \%$ and the bottom $50 \%$ (Table

\footnotetext{
${ }^{16}$ These results also hold when considering only the original data with no further adjustments imputing bank deposits, non nominative and undistributed profits.
} 
5). At the same time, the post tax participation of the top $0.1 \%$ is halved.

Table 5: Post-tax income shares, 2009-2016

\begin{tabular}{lcccccccc}
\hline Inc. groups & 2009 & 2010 & 2011 & 2012 & 2013 & 2014 & 2015 & 2016 \\
\hline \multicolumn{7}{c}{} & \multicolumn{7}{c}{ Pre-tax } \\
\hline Top 0.1\% & $5,0 \%$ & $5,1 \%$ & $5,5 \%$ & $5,3 \%$ & $5,6 \%$ & $5,3 \%$ & $5,9 \%$ & $6,4 \%$ \\
Top 1\% & $14,7 \%$ & $14,7 \%$ & $15,1 \%$ & $14,8 \%$ & $14,8 \%$ & $14,6 \%$ & $15,3 \%$ & $16,2 \%$ \\
Top 10\% & $47,5 \%$ & $47,2 \%$ & $46,6 \%$ & $46,5 \%$ & $45,8 \%$ & $45,6 \%$ & $45,8 \%$ & $46,6 \%$ \\
Middle 40\% & $42,5 \%$ & $42,6 \%$ & $42,9 \%$ & $43,0 \%$ & $43,6 \%$ & $43,8 \%$ & $43,4 \%$ & $42,9 \%$ \\
Bottom 50\% & $10,0 \%$ & $10,2 \%$ & $10,5 \%$ & $10,5 \%$ & $10,6 \%$ & $10,7 \%$ & $10,8 \%$ & $10,5 \%$ \\
\hline \multicolumn{7}{c}{ Post-tax } \\
Top 0.1\% & $3,1 \%$ & $3,7 \%$ & $3,9 \%$ & $3,1 \%$ & $3,8 \%$ & $3,5 \%$ & $3,6 \%$ & $3,5 \%$ \\
Top 1\% & $12,9 \%$ & $13,1 \%$ & $13,3 \%$ & $12,7 \%$ & $12,9 \%$ & $12,8 \%$ & $13,3 \%$ & $14,2 \%$ \\
Top 10\% & $45,1 \%$ & $44,8 \%$ & $44,4 \%$ & $44,0 \%$ & $43,0 \%$ & $42,9 \%$ & $43,1 \%$ & $43,9 \%$ \\
Middle 40\% & $44,6 \%$ & $44,7 \%$ & $45,1 \%$ & $45,1 \%$ & $45,7 \%$ & $45,8 \%$ & $45,4 \%$ & $45,0 \%$ \\
Bottom 50\% & $10,3 \%$ & $10,5 \%$ & $10,5 \%$ & $10,9 \%$ & $11,3 \%$ & $11,3 \%$ & $11,5 \%$ & $11,2 \%$ \\
\hline
\end{tabular}

Note. Own elaboration based on tax records (DGI). Pre and post-tax shares presented in the first and second panel respectively.

\subsubsection{Reconciling synthetic indices and top income shares}

The increase in top incomes shares depicted by DGI data was relatively small and it is not statistically significant. However, one striking feature of Table 6 relies in the comparative evolution of the $1 \%$ share in the two data sources. Whereas in 2009 the DGI/ECH ratio was $85 \%$, it fell to $55 \%$ in 2016 . Thus, differently to synthetic indices, in this case results are sensitive to the data source.

The ECH/DGI ratios of the lower thresholds and average income for the top $10 \%$ and $1 \%$ shares suggest that the erosion of ECH took place among the higher strata. In fact, the $10 \%$ threshold is very similar in the two data sources, with almost constant ratios above $90 \%$ in the whole period. However, in the case of the top 1\%, this ratio falls from almost 90 to $74 \%$. As expected, this loss in ECH's capacity to reach the higher strata increases with income (as highlighted in the comparison between the means ECH/DGI ratios for the two fractiles).

Assessing the reasons under this impoverishment in ECHs ability to capture the richest strata and the consequent decline in the ratios examined in the previous paragraph, is beyond the scope of this study. However, some conjectures can be raised considering that this occurred in a period of rapid income growth coupled with increased residential segregation (Rodríguez Vivas, 2019), and underreporting and refusal rates might have increased. On the side of DGI data, two main features might create an artificial inequality increase: reduced informality with the subsequent entries of low salaried workers in the data-base and a higher ability of the tax authority to enforce 
Table 6: Top shares comparison by data source, 2009-2016

\begin{tabular}{c|cc|cc|cc}
\hline & \multicolumn{2}{|c|}{ Top 1\% share } & \multicolumn{2}{|c|}{ Top 1\% Survey/Tax records } & \multicolumn{2}{|c}{ Top 10\% Survey/Tax records } \\
Year & Tax records & Harmonized survey & Threshold & Mean & Threshold & Mean \\
\hline 2009 & $14.7 \%$ & $11.5 \%$ & $88.2 \%$ & $74.7 \%$ & $93.6 \%$ & $86.2 \%$ \\
2010 & $14.7 \%$ & $10.6 \%$ & $83.7 \%$ & $65.4 \%$ & $89.6 \%$ & $80.1 \%$ \\
2011 & $15.1 \%$ & $9.5 \%$ & $79.0 \%$ & $56.5 \%$ & $91.8 \%$ & $76.8 \%$ \\
2012 & $14.8 \%$ & $7.7 \%$ & $68.8 \%$ & $45.3 \%$ & $90.4 \%$ & $69.6 \%$ \\
2013 & $14.8 \%$ & $8.5 \%$ & $74.2 \%$ & $49.9 \%$ & $90.0 \%$ & $72.5 \%$ \\
2014 & $14.6 \%$ & $8.4 \%$ & $74.8 \%$ & $49.9 \%$ & $89.3 \%$ & $72.2 \%$ \\
2015 & $15.3 \%$ & $8.7 \%$ & $77.2 \%$ & $51.5 \%$ & $93.7 \%$ & $75.0 \%$ \\
2016 & $16.2 \%$ & $8.4 \%$ & $73.9 \%$ & $45.2 \%$ & $90.7 \%$ & $70.0 \%$ \\
\hline
\end{tabular}

Note. Own calculations based on tax records (DGI) and household surveys (ECH). The first block depicts top $1 \%$ 's share in the tax records and harmonized survey.

tax-payers.

To dig into the conflicting trends depicted by top income shares vis a vis synthetic indices in DGI data, we carried out two group decompositions considering the following income categories: bottom 50\%; middle (50-90\%); middle-top (90-99\%) and top (99-100\%), and bottom 99\% versus top 1\% (Tables A.10 and 7). Although the aforementioned tables depict pre-tax income decompositions, the results and comments presented under this heading also hold for post-tax income based inequality indices in the two data-sources. ${ }^{17}$

The between group inequality fraction remained steady throughout the years in the Gini and Theil indices decompositions at DGI data. However, the last rows of the top panel clearly convey a remarkable contrast: whereas inequality decreased for the 3 poorer groups (with 2013 to 2009 ratios being 95.7, 90.4 and 97.2\% respectively), a sharp increase was going on at the top throughout the whole period $(2013 / 09$ ratio $=1.13 \%) \cdot 18$ However, carrying out the same decomposition with harmonized ECH micro-data (bottom panel), yields to falling between group inequality. Recall that, at the same time, Gini and Theil indices fall monotonically in the four groups, with a larger fall at the top $1 \%$ (the 2016 to 2013 ratio is $92.4,92.1,86.3$ and $67.0 \%$ respectively).

In the second variant (Table 7) we collapsed the first three groups into one category. In this case, the "explanatory power" of between groups inequality also grew at DGI micro-data, highlighting the increased distance in the two groups average income. At the same time, this exercise yields, again, a sharp contrast between the 2009-2016 decreasing inequality trend of the bottom $99 \%$ (6\% fall) and the opposite movement at the top 1\% (20\% increase). Similar results are obtained from the Theil index decomposition. Again, this result diverges from the findings at ECH micro-data (bottom panel) where, as in the case of the first exercise, both the between

\footnotetext{
${ }^{17}$ Due to space constrain additional tables are not included in this document, but they are available upon request to the authors.

${ }^{18}$ These results also hold when considering only the original data with no further adjustments imputing bank deposits, non nominative and undistributed profits).
} 
Table 7: Inequality decomposition between two income groups, 2009-2016.

\begin{tabular}{llllllllll}
\hline & 2009 & 2010 & 2011 & 2012 & 2013 & 2014 & 2015 & 2016 \\
\hline \multicolumn{7}{c}{} & \multicolumn{7}{c}{ Tax records (DGI) } \\
\hline Gini index & 0,574 & 0,570 & 0,565 & 0,561 & 0,554 & 0,552 & 0,552 & 0,560 \\
Between & 0,125 & 0,125 & 0,129 & 0,126 & 0,126 & 0,125 & 0,131 & 0,141 \\
Within & 0,449 & 0,445 & 0,435 & 0,435 & 0,427 & 0,427 & 0,421 & 0,419 \\
Overlap & 0,000 & 0,000 & 0,000 & 0,000 & 0,000 & 0,000 & 0,000 & 0,000 \\
\hline Between (\%) & 21,8 & 21,9 & 22,9 & 22,4 & 22,8 & 22,7 & 23,8 & 25,2 \\
Within (\%) & 78,2 & 78,1 & 77,1 & 77,6 & 77,2 & 77,3 & 76,2 & 74,8 \\
Overlap (\%) & 0,0 & 0,0 & 0,0 & 0,0 & 0,0 & 0,0 & 0,0 & 0,0 \\
\hline Bottom 99\% & 0,524 & 0,519 & 0,510 & 0,508 & 0,499 & 0,498 & 0,494 & 0,497 \\
Top 1\% & 0,355 & 0,364 & 0,390 & 0,383 & 0,400 & 0,385 & 0,408 & 0,423 \\
\hline & & & Harmonized survey (ECH) & & \\
\hline Gini index & 0,581 & 0,569 & 0,561 & 0,544 & 0,547 & 0,541 & 0,555 & 0,551 \\
Between & 0,105 & 0,096 & 0,085 & 0,067 & 0,075 & 0,074 & 0,077 & 0,074 \\
Within & 0,476 & 0,473 & 0,476 & 0,477 & 0,472 & 0,467 & 0,478 & 0,476 \\
Overlap & 0,000 & 0,000 & 0,000 & 0,000 & 0,000 & 0,000 & 0,000 & 0,000 \\
\hline Between (\%) & 18,0 & 16,8 & 15,2 & 12,4 & 13,7 & 13,7 & 13,8 & 13,5 \\
Within (\%) & 82,0 & 83,2 & 84,8 & 87,6 & 86,3 & 86,3 & 86,2 & 86,5 \\
Overlap (\%) & 0,0 & 0,0 & 0,0 & 0,0 & 0,0 & 0,0 & 0,0 & 0,0 \\
\hline Bottom 99\% & 0,543 & 0,534 & 0,531 & 0,522 & 0,521 & 0,515 & 0,529 & 0,525 \\
Top 1\% & 0,254 & 0,227 & 0,202 & 0,136 & 0,172 & 0,173 & 0,191 & 0,180 \\
\hline
\end{tabular}

Note. Own calculations based on tax records (DGI) and household surveys (ECH). The table is divided in two panels, depicting tax records and harmonized surveys respectively. By construction, both micro-data bases refer to the same individuals and same incomes (pre-tax and formal total personal incomes). In each panel, Gini index is decomposed in between and within components, among the groups defined (bottom $99 \%$ and top 1\%). Within group inequality is depicted in the last two rows of each panel.

groups proportion and intra group inequality fell.

Thus, decreasing inequality at the bottom $99 \%$ (jointly considered or split into 3 groups) coupled with increased concentration at the top $1 \%$ is consistent with trends observed in ECH and its apparently reduced capacity to reach the rich. This finding is mirrored by the falling $\mathrm{ECH} / \mathrm{DGI}$ average income ratio at the top $1 \%$ presented in 4.1 .2 . Whereas inequality reduction in harmonized ECH was led by the $90-99 \%$ and top $1 \%$ groups, the opposite happened in DGI, with equalisation mainly occurring at the bottom 50 and 50-90\% groups.

The mild inequality reduction observed in DGI data reflects an offsetting fall in the $99 \%$ against an increasing concentration at the top, that results in increased/stable shares. At the same time, at ECH the inequality reduction is also fed by a better distribution in all groups (with larger reductions at the top). The latter can result either from richer households increased refusal rates or underreporting.

To conclude this subsection, three comments are noteworthy. First of all, the evolution 
of inequality at the bottom $50 \%$ rules out the possibility of DGI trends being driven by the formalization process. Secondly, and more important, the evolution of inequality at the top $1 \%$ is consistent with the observed divergence in the DGI versus ECH share of this group. Thirdly, DGI figures suggest that the $99 \%$ group inequality fall took was coupled with augmented inequality at the top led by this groups increased earnings.

\subsection{The composition of income}

The last subsection concluded that the main diverging point in the two databases used in this research refers to inequality and average income at the top of the income distribution. Thus, the ability of ECH and DGI to capture the different income sources can contribute to the explanation of these discrepancies, particularly regarding capital income. To explore this hypothesis, we analyzed the four income sources described in Section 3.1.1. labour, pensions, mixed income (i.e., liberal professionals earnings) and capital income (separately considering property rents, bank deposits profits and other items).

The findings presented in the previous paragraphs closely relate to the source composition of the different population groups. In fact, Table A.11 and Table A.12 depict the relative participation at DGI and ECH data of the four income groups previously considered, uncovering the expected pattern: labour income accounts for around $75 \%$ of total income at ECH, falling to $66 \%$ in DGI data. Since the weight of pensions is similar in the two data-sources, the difference is entirely explained by the capital income share which is around three and four times larger in tax database and grows throughout the period, whereas it falls in household survey data. Again, this pattern is consistent with the different trends observed in the two data-sets in the evolution of top incomes shares.

Inspecting the income source composition in DGI data, it can be noticed that, at the bottom $99 \%$, the largest share corresponds to labour earnings and pensions, with a slight but increasing participation of mixed and capital income. Meanwhile, in 2016 the latter two sources equalize labour earnings at the top $1 \%$ and surpass it at the top $0.1 \% 19$ In regard to capital income, profits are clearly the most unequally distributed source. Whereas property rents are more relevant for centiles 90-99, at the top, profits account for around $45 \%$ of capital income. This predominance of capital income and profits at the richest strata has been highlighted by the top incomes literature as a distinctive feature of developing countries, since in the developed world, executives compensations and high salaried workers have a larger participation at the top Alvaredo and Londoño Velez, 2014).

At the same time, it is worth pointing out the substantial increase of the share capital income at the top throughout the whole period, which is in line with its augmented share previously mentioned. As a matter of fact, our estimations also indicate that whereas in harmonized ECH

\footnotetext{
${ }^{19}$ Due to the number of cases, these estimations cannot be carried out with ECH micro-data.
} 
the top $1 \%$ receives $37 \%$ of total capital income, this figure rises to $62 \%$ in DGI micro-data.

Tables 8 and A.12 depict the results of the Lerman and Yitzhaki (1985) Gini index income source decomposition based on DGI and ECH micro-data respectively. As expected, capital income is the most unequally distributed income source (with a Gini index very close to 1), followed by pensions (which probably is related to the number of individuals not being pensioners). $R$ values clearly show that, in spite of its tiny share, capital income is largely correlated to total income. However, the decomposition yields to different patterns in the two data sources, with a larger share of labour income in ECH data. Conversely, the contribution of capital income and pensions is substantially larger in DGI, with an increasing share in the latter case. Finally, the negative sign of the marginal contribution of pensions to inequality indicates their equalizing effect, which is higher in ECH than in DGI. Labour and capital income exhibit a positive contribution in the two data sources, with the expected order and trend.

Table 8: Inequality decomposition by income source. 2009, 2013 and 2016. (DGI Pre-tax income)

\begin{tabular}{|c|c|c|c|c|c|c|c|c|c|}
\hline & & 2009 & 2010 & 2011 & 2012 & 2013 & 2014 & 2015 & 2016 \\
\hline \multirow{4}{*}{ Sk } & Labor inc. & 0,693 & 0,694 & 0,711 & 0,682 & 0,684 & 0,683 & 0,674 & 0,677 \\
\hline & Pensions & 0,228 & 0,230 & 0,202 & 0,225 & 0,222 & 0,218 & 0,222 & 0,218 \\
\hline & Capital inc. & 0,068 & 0,065 & 0,075 & 0,082 & 0,083 & 0,088 & 0,093 & 0,095 \\
\hline & Mixed inc. & 0,011 & 0,011 & 0,011 & 0,011 & 0,011 & 0,011 & 0,010 & 0,010 \\
\hline \multirow{4}{*}{ Gk } & Labor inc. & 0,707 & 0,707 & 0,689 & 0,696 & 0,684 & 0,680 & 0,678 & 0,685 \\
\hline & Pensions & 0,818 & 0,811 & 0,821 & 0,809 & 0,812 & 0,812 & 0,811 & 0,809 \\
\hline & Capital inc. & 0,989 & 0,989 & 0,991 & 0,984 & 0,985 & 0,986 & 0,990 & 0,990 \\
\hline & Mixed inc. & 0,999 & 0,999 & 0,999 & 0,999 & 0,999 & 0,999 & 0,999 & 0,999 \\
\hline \multirow{4}{*}{$\mathrm{Rk}$} & Labor inc. & 0,859 & 0,861 & 0,869 & 0,852 & 0,851 & 0,850 & 0,845 & 0,845 \\
\hline & Pensions & 0,446 & 0,430 & 0,370 & 0,412 & 0,401 & 0,391 & 0,395 & 0,395 \\
\hline & Capital inc. & 0,890 & 0,882 & 0,893 & 0,893 & 0,892 & 0,897 & 0,904 & 0,904 \\
\hline & Mixed inc. & 0,968 & 0,968 & 0,969 & 0,960 & 0,960 & 0,960 & 0,960 & 0,960 \\
\hline \multirow{4}{*}{ Share } & Labor inc. & 0,732 & 0,741 & 0,754 & 0,720 & 0,719 & 0,715 & 0,701 & 0,708 \\
\hline & Pensions & 0,145 & 0,141 & 0,109 & 0,133 & 0,130 & 0,125 & 0,129 & 0,122 \\
\hline & Capital inc. & 0,105 & 0,099 & 0,117 & 0,128 & 0,132 & 0,141 & 0,152 & 0,152 \\
\hline & Mixed inc. & 0,011 & 0,011 & 0,011 & 0,011 & 0,011 & 0,011 & 0,010 & 0,010 \\
\hline \multirow{4}{*}{ Change (\%) } & Labor inc. & 0,039 & 0,047 & 0,043 & 0,038 & 0,035 & 0,032 & 0,027 & 0,032 \\
\hline & Pensions & $-0,083$ & $-0,089$ & $-0,094$ & $-0,092$ & $-0,091$ & $-0,093$ & $-0,093$ & $-0,096$ \\
\hline & Capital inc. & 0,036 & 0,034 & 0,043 & 0,046 & 0,049 & 0,053 & 0,058 & 0,057 \\
\hline & Mixed inc. & 0,008 & 0,008 & 0,008 & 0,008 & 0,008 & 0,008 & 0,008 & 0,008 \\
\hline
\end{tabular}

Note. Own elaboration based on tax records (DGI). Gini index income source decomposition Lerman and Yitzhaki (1985)) is depicted. $k$ is income source, $S$ is the income share, $G$ is the within source Gini index, $R$ reports the correlation among each income source and total Gini, share represents the contribution of each source to overall inequality and change is the marginal effect of a $1 \%$ increase.

In line with previous studies on wage differentials, when opening the income distribution by source and gender, our estimations show that the participation of women in total and labour income decrease with the quantile (Figure 4, panel a), ranging from more than $50 \%$ below the median to $25 \%$ at the highest percentile. Estimations by Atkinson et al. (2018) for eight high 
income countries find similar results. The presence of women is larger among pensioners, probably due to life expectancy patterns, but it reflects the same declining shape, although differences are smaller (60\% and 40\% respectively). Conversely, the presence of women is scarcer among mixed and capital income receivers. Considering the distribution of income instead of the number of earners (panel b) results are very similar, although in most cases women's share is even lower, probably reflecting their relative disadvantage within categories.

Figure 4: Proportion of female earners and women's income share by source and income fractile.

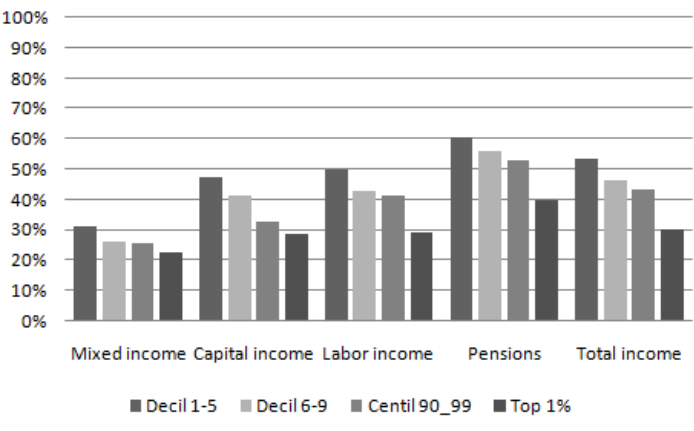

(a) Percentage of women

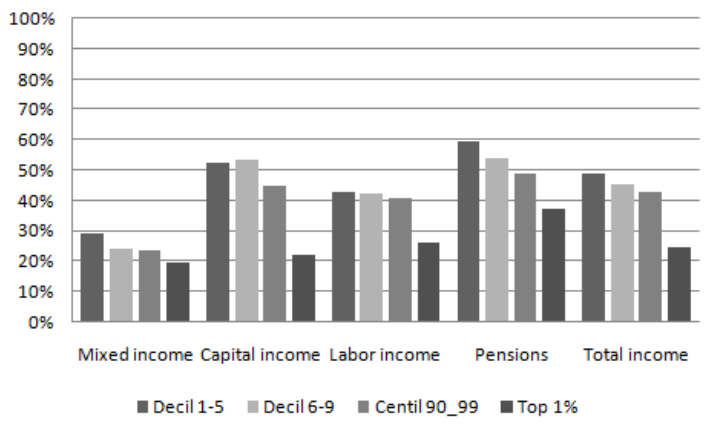

(b) Women's income share

Note. Own calculation based on tax records (DGI). The percentage of female earners and their income share (by income source and fractile), are depicted in panels (a) and (b) respectively.

To conclude this analysis, we briefly comment on the effective tax rates paid by income source and income centile according to DGI information (Figure 5). As a whole, it can be noticed that total labour earnings depict a progressive scheme, with the minimum taxable income above the median, and respectively reaching $15 \%$ at the highest centile and rising to $18 \%$ at the top $0.1 \%$. Conversely, capital income rates are steady until percentile 80 and decrease thereafter.

The reasons under this decline refer to the different tax rates within this source depicted in Table A.1: at the top, the relative share of profits increases and this sub-source faces a lower rate than property rents and bank deposits. As a result, tax rates effectively paid by the top $1 \%$ are lower, In turn, the same pattern holds for the top fractiles (0.5 and $0.1 \%)$. This regressive capital income taxation scheme affects total effective rates. Even when they exhibit a progressive pattern for the first 99 percentiles, they fall from $11.5 \%$ for the top $1 \%$ to $9.5 \%$ for the top $0.1 \%$.

Although these effective rates are relatively low when compared to OECD countries, they double the estimations for Colombia (Alvaredo and Londoño Velez, 2014). In regard to the potential simulation exercises to inform further tax reforms it is worth pointing out that, consistently with its lower outreach capacity of the higher strata and particularly of capital income, ECH depicts a more progressive pattern at the top fractiles with higher effective rates $(12.2 \%$ for the top $1 \%$ to $13.6 \%$ for the top $0.1 \%$ ) than DGI micro-data. 
Figure 5: Effective tax rates by income source

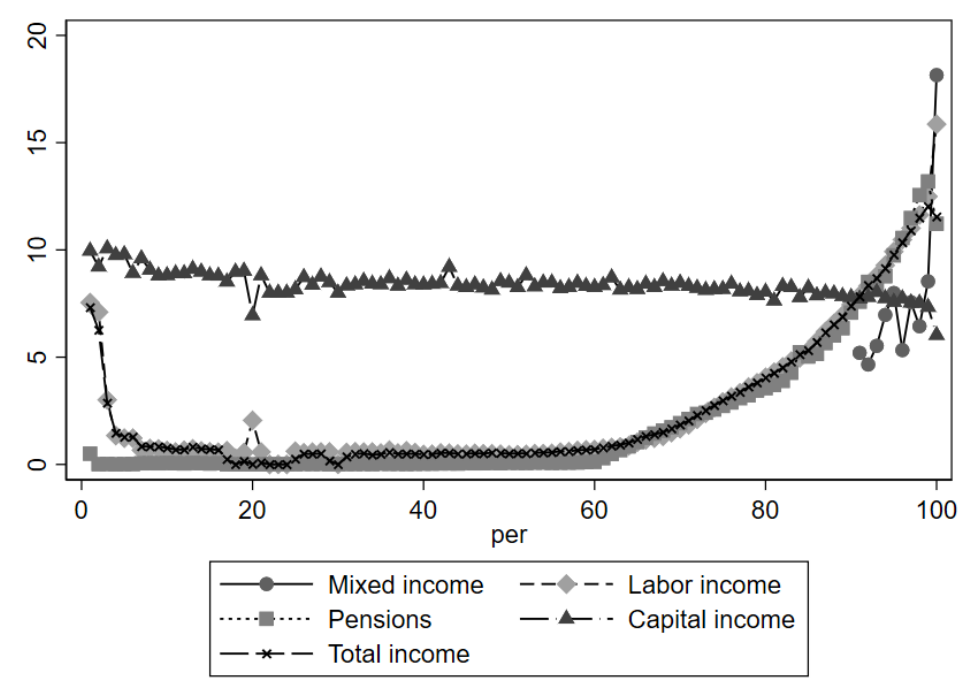

Note. Own calculations based on tax records (DGI). Effective tax rates for total income and all income sources are depicted.

\subsection{Income mobility patterns}

The previous subsections presented an overview of the recent evolution of inequality among income earners in Uruguay overlooking individual trajectories. However, it might be argued that if there is enough mobility and income distances are relatively short, individuals might occupy different positions in the income distribution across their lives or within a particular span Auten et al. 2013 , Kopczuk et al. 2010). At the same, since in previous sections we have shown that the top $1 \%$ accrues the same portion of total income that the bottom $50 \%$, persistence in top income positions can be understood as an indicator of the concentration of economic decisions and power. Thus, a complete appraisal of economic well-being disparities requires also examining mobility and its interplay with inequality (Aaberge and Mogstad, 2015; Shorrocks, 1978, 1981).

To address these topics, we exploit the panel structure of DGI micro-data ${ }^{20}$ However, rather than providing a complete picture of intra-generational mobility in a short or medium time-span, our main purposes here are to illustrate the bidirectional links between mobility and inequality, without addressing potential causality issues. We first analyze absolute and positional mobility patterns across the income distribution exploring whether mobility levels varied in the period of larger inequality fall 4.3.1). After that, we explore the extent of persistence in top income positions 4.3.2). Finally, we analyze the distributional effect of income mobility 4.3.3).

\footnotetext{
${ }^{20}$ Since ECH is a cross-sectional data-set, we restrict our study to the individuals included at DGI micro-data, eliminating the cases we added corresponding to informal workers
} 


\subsubsection{Mobility patterns, top income holders and inequality}

To conduct the mobility analysis, we restricted DGI micro-data to the balanced panel, i.e., those individuals reporting positive incomes in the eight years, leading to exclude $56 \%$ of observations. ${ }^{21}$ To assess whether mobility patterns relate to the evolution of the income distribution, we split the sample in sub-periods according to the inequality trends identified in previous sections $(2009 / 2013$ and $2013 / 2016)$.

Annual entry and exit flows comprise approximately $7 \%$ and $5 \%$ of individuals in the panel respectively (Table A.13). Flows decrease with age and show no particular pattern when disaggregated by gender. As expected, retired individuals exhibits lower entry and exit rates. Self-employed workers and capital income earners present larger inflow rates, probably reflecting increasing employment formalization and the expansion of the personal income tax system, respectively.

To assess panel flows patterns regarding individuals' position in the income distribution, we built total pre-tax income vintiles under two variants. The first one was based on the longitudinally-averaged total income in real terms at 2016 prices. Instead, in the second one, we considered individuals' income at the time of entry. In the two cases, entry and exit rates are decreasing in income, particularly until the fourth vintile, where they stabilize (Figure A.2. This result is consistent with the location of the minimum taxable income threshold.

We first estimated average absolute and positional correlations ( $\beta$ coefficients) opened by gender and sub-period under different options, in order to assess the sensitiveness of the coefficients (Tables 9 and A.14). Considering the whole period, the average absolute persistence rate is 0.6, with slight variations by gender ( 0.62 for women and 0.58 for men). In this case, recalling the results obtained in sub-section 4.3.2, similar mobility opportunities are indicating that women were not able to climb to the higher income strata.

Disaggregations for shorter periods of time yield, as expected, to larger coefficients. In spite of that, a remarkable result is that when comparing sub-periods of similar length, persistence rates are lower during the inequality reduction time-span. Thus, after 2013 estimates yield to extremely high values indicating very low mobility levels. An interesting feature relies in the fact that even when $\beta$ coefficients are very high and almost converged after redistribution ceased, in the period of inequality reduction the gap among women and men widened in favour of the latter. These results suggest that the gender gap remained steady or even grew throughout the period.

However, ranking based estimations yield approximately $25 \%$ higher immobility rates in the 2009-2016 estimations (0.75, 0.76 and 0.74 for the entire population, women and men respectively), suggesting that increased income was not necessarily translated in re-ranking. A second feature

\footnotetext{
${ }^{21}$ Individuals with zero or negative income in at least one period were also excluded. Burdín et al. (2014b) compare the balanced and unbalanced panel for 2009-2012 in terms of individual characteristics and income. As expected, to balance the panel introduces a moderate bias toward older individuals, pensioners and top income earners.
} 
Table 9: Intragenerational elasticity. Log of income 2016-2009

\begin{tabular}{|c|c|c|c|c|c|c|}
\hline & \multicolumn{6}{|c|}{ Log of income (final year) } \\
\hline & $2009 / 2016$ & $2009 / 2012$ & $2010 / 2013$ & $2011 / 2014$ & $2012 / 2015$ & $2013 / 2016$ \\
\hline \multirow[t]{2}{*}{ Log of income (initial year) } & $0.603^{* * *}$ & $0.682^{* * *}$ & $0.764^{* * *}$ & $0.764^{* * *}$ & $0.785^{* * *}$ & $0.830^{* * *}$ \\
\hline & $(0.00113)$ & $(0.00112)$ & $(0.00121)$ & $(0.00139)$ & $(0.00154)$ & $(0.00127)$ \\
\hline Observations & $1,040,140$ & $1,040,140$ & $1,040,140$ & $1,040,140$ & $1,040,140$ & $1,040,140$ \\
\hline \multirow[t]{2}{*}{ R-squared } & 0.502 & 0.627 & 0.696 & 0.688 & 0.692 & 0.674 \\
\hline & \multicolumn{6}{|c|}{ Women } \\
\hline \multirow[t]{2}{*}{ Log of income (initial year) } & $0.621^{* * *}$ & $0.710^{* * *}$ & $0.785^{* * *}$ & $0.795^{* * *}$ & $0.808^{* * *}$ & $0.845^{* * *}$ \\
\hline & $(0.00148)$ & $(0.00147)$ & $(0.00150)$ & $(0.00166)$ & $(0.00168)$ & $(0.00145)$ \\
\hline Observations & 542,810 & 550,263 & 545,563 & 545,656 & 543,403 & 541,025 \\
\hline \multirow[t]{2}{*}{ R-squared } & 0.528 & 0.655 & 0.723 & 0.724 & 0.724 & 0.707 \\
\hline & \multicolumn{6}{|c|}{ Men } \\
\hline \multirow[t]{2}{*}{ Log of income (initial year) } & $0.581^{* * *}$ & $0.648^{* * *}$ & $0.732^{* * *}$ & $0.719^{* * *}$ & $0.750^{* * *}$ & $0.835^{* * *}$ \\
\hline & $(0.00173)$ & $(0.00172)$ & $(0.00200)$ & $(0.00233)$ & $(0.00277)$ & $(0.00187)$ \\
\hline Observations & 495,587 & 489,181 & 482,111 & 483,585 & 479,467 & 477,069 \\
\hline R-squared & 0.461 & 0.567 & 0.652 & 0.632 & 0.639 & 0.640 \\
\hline
\end{tabular}

Note. Own calculations based on tax records (DGI). Coefficients of log of income of end year against log of income for base year (with sex, age groups and a dummy for capital income receivers as covariates). In each column, a different set of base/end year is presented. The first panel refers to the whole population, the second restricts the sample to women and the last, to men.

Robust standard errors in parentheses ${ }^{* * *} \mathrm{p}<0.01,{ }^{* *} \mathrm{p}<0.05,{ }^{*} \mathrm{p}<0.1$.

of this group of estimations is that, even when the negative association among persistence and inequality reduction still holds, differences across sub-periods were more subtle. At the same time, since coefficients tended to converge, gender distances remained steady or were even reinforced.

The precedent estimations provided a picture for the overall population, without digging into differences by income strata. Transition matrices allow for comparing incomes classes, with the main diagonal providing information on persistence rates, understood as the proportion of individuals remaining in their initial income fractile. Results indicate a remarkable monotonically increasing pattern of persistence in the upper half of the income distribution. Interestingly, approximately $70 \%$ of individuals in the 10th decile in 2009 remained in that position seven years later. This value is more than three times higher than the persistence rate exhibited by those individuals in the 5 th decile.

Again, there are scarce differences by gender, although, as expected, persistence rates among women are higher in the lower strata and the reverse relation holds above the median (Tables A.16, A.17 A.18 and A.19). Differences by sub-period also reinforce the regression analysis results, with higher mobility, particularly at the top decile and vintile in the period of inequality fall versus the subsequent years (persistence rates at the top decile were $75.2 \%$ and $79.7 \%$ and rose to $87.4 \%$ and $90.7 \%$ at the top ventile).

Considering their different incidence across the income distribution, we analyzed the extent of 
Table 10: Transition matrix, 2009-2016

\begin{tabular}{|c|c|c|c|c|c|c|c|c|c|c|c|c|}
\hline \multirow[b]{2}{*}{2009} & \multicolumn{12}{|c|}{2016} \\
\hline & Decil 1 & Decil 2 & Decil 3 & Decil 4 & Decil 5 & Decil 6 & Decil 7 & Decil 8 & Decil 9 & Decil 10 & Top 5 & Top 1 \\
\hline Decil 1 & $32.9 \%$ & $24.9 \%$ & $11.1 \%$ & $9.5 \%$ & $8.7 \%$ & $6.8 \%$ & $4.9 \%$ & $3.5 \%$ & $2.4 \%$ & $1.2 \%$ & $1.0 \%$ & $1.0 \%$ \\
\hline Decil 2 & $36.9 \%$ & $35.7 \%$ & $8.7 \%$ & $6.6 \%$ & $4.8 \%$ & $3.6 \%$ & $2.4 \%$ & $1.7 \%$ & $1.1 \%$ & $0.6 \%$ & $0.4 \%$ & $0.5 \%$ \\
\hline Decil 3 & $7.9 \%$ & $24.0 \%$ & $26.6 \%$ & $9.7 \%$ & $6.7 \%$ & $5.0 \%$ & $3.6 \%$ & $2.6 \%$ & $1.7 \%$ & $0.8 \%$ & $0.7 \%$ & $0.9 \%$ \\
\hline Decil 4 & $6.9 \%$ & $5.9 \%$ & $33.6 \%$ & $23.0 \%$ & $12.7 \%$ & $7.9 \%$ & $5.3 \%$ & $3.7 \%$ & $2.3 \%$ & $1.1 \%$ & $0.9 \%$ & $1.1 \%$ \\
\hline Decil 5 & $5.2 \%$ & $4.4 \%$ & $6.9 \%$ & $31.6 \%$ & $20.7 \%$ & $12.7 \%$ & $8.2 \%$ & $5.6 \%$ & $3.5 \%$ & $1.5 \%$ & $1.2 \%$ & $1.4 \%$ \\
\hline Decil 6 & $3.5 \%$ & $2.7 \%$ & $5.9 \%$ & $7.4 \%$ & $28.7 \%$ & $21.7 \%$ & $13.6 \%$ & $9.3 \%$ & $5.4 \%$ & $2.1 \%$ & $1.6 \%$ & $1.8 \%$ \\
\hline Decil 7 & $2.5 \%$ & $1.1 \%$ & $4.1 \%$ & $5.8 \%$ & $7.5 \%$ & $26.8 \%$ & $25.5 \%$ & $14.9 \%$ & $9.1 \%$ & $3.0 \%$ & $2.0 \%$ & $2.1 \%$ \\
\hline Decil 8 & $1.8 \%$ & $0.6 \%$ & $1.8 \%$ & $4.0 \%$ & $5.8 \%$ & $7.8 \%$ & $24.1 \%$ & $30.6 \%$ & $17.9 \%$ & $5.6 \%$ & $3.3 \%$ & $2.8 \%$ \\
\hline Decil 9 & $1.3 \%$ & $0.4 \%$ & $0.9 \%$ & $1.6 \%$ & $3.4 \%$ & $6.0 \%$ & $8.6 \%$ & $20.8 \%$ & $40.6 \%$ & $16.5 \%$ & $8.1 \%$ & $4.9 \%$ \\
\hline Decil 10 & $1.1 \%$ & $0.3 \%$ & $0.6 \%$ & $0.7 \%$ & $1.0 \%$ & $1.8 \%$ & $3.7 \%$ & $7.3 \%$ & $16.1 \%$ & $67.6 \%$ & $80.7 \%$ & $83.7 \%$ \\
\hline Top 5 & $0.5 \%$ & $0.1 \%$ & $0.3 \%$ & $0.3 \%$ & $0.4 \%$ & $0.5 \%$ & $0.9 \%$ & $2.6 \%$ & $3.7 \%$ & $40.7 \%$ & $64.9 \%$ & $77.9 \%$ \\
\hline Top 1 & $0.1 \%$ & $0.0 \%$ & $0.1 \%$ & $0.1 \%$ & $0.1 \%$ & $0.1 \%$ & $0.2 \%$ & $0.3 \%$ & $0.4 \%$ & $8.6 \%$ & $15.7 \%$ & $52.2 \%$ \\
\hline
\end{tabular}

Note. Own calculations based on tax records (DGI). In each cell, the percentage of individuals that were located in a given income group in 2009 (rows) and were part of an income group in 2016 (columns) is depicted. Income groups for both years are the ten deciles of total income, top $5 \%$ and top $1 \%$.

income mobility for different income sources ${ }^{22}$, reporting summary mobility indicators from deciles transition matrices (Table A.15). Persistence levels are heterogeneous across income sources and capital income can be singled out as the most immobile income source. Labour earnings appear to occupy an intermediate position in terms of mobility.

Figure 6 plots persistence rates by income source computed as the fraction of individuals remaining either in the same or an adjacent position in the income distribution. Persistence rates increase monotonically from the 10th vintile onward. While labour income mimics the pattern of total income, capital income exhibits a more irregular pattern, since this source becomes noticeable at the top of the distribution. Persistence rises rapidly in top sectors, surpassing labour income at the top $5 \%$.

\footnotetext{
${ }^{22}$ We define individuals earning a given income source as those for whom that source surpasses $50 \%$ of their total income.
} 
Figure 6: Persistence rates 2009-2016

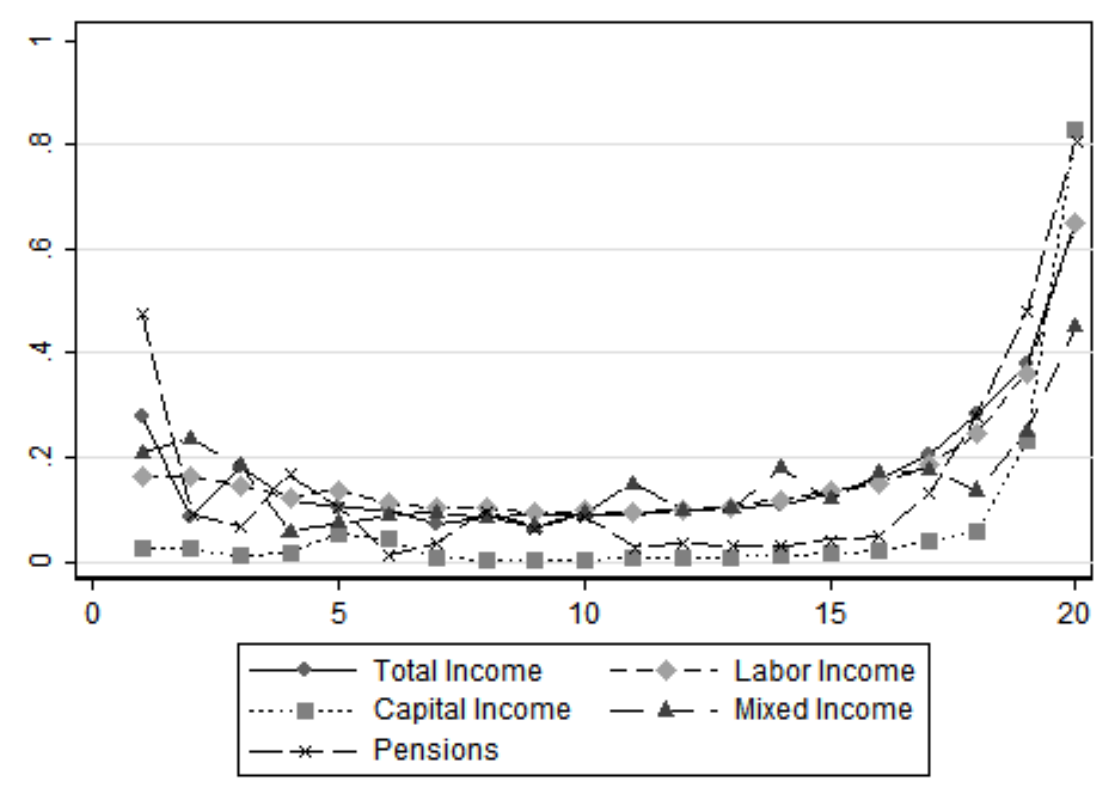

Note. On calculations based on tax records (DGI). Vintiles correspond to 2009 income.

\subsubsection{Income mobility at the top}

In this section, we scrutinize movements in and out top income groups. Fractile transition matrices indicate that approximately $70 \%$ of individuals located in the bottom half of the total income initial distribution remained in the same position in 2016. Barely only $1 \%$ of these individuals were able to enter into the top $10 \%$. Similarly, among those in the top $1 \%$ in 2009 , only $8 \%$ moved to the bottom $90 \%$ in 2016 . Thus, positional changes mainly occurred within the top $10 \%$.

Figure 7 plots the probability of remaining in a certain top income fractile (top 5\%, 1\%, $0.5 \%$ and $0.1 \%$ ) after one (panel a) and three years (panel b). Annual persistence rates appear to be very stable above $50 \%$ in all cases and first three groups surpass $70 \%$. The probability of remaining at the top $5 \%$ after 1 year is around $90 \%$ and falls to $80 \%$ for the top $1 \%$. Persistence rates after 3 years are lower but remain high and stable, except for the top $0.1 \%$ that rises at the end of the time span considered. Even when women are underrepresented in these strata, no remarkable differences by gender are found (Table A.4).

The resulting persistence rates for top income groups are in line with previous estimates for developed countries. For instance, the probability of remaining at the top $1 \%$ after one year is $78 \%$ for Germany (Jenderny, 2016). Moreover, persistence rates at the top $0.1 \%$ are around $70 \%$, $60 \%$, and 67\% in Germany (2001-2006), Canada (1988-2000) and France (1998-2003) respectively (Jenderny, 2016, Saez and Veall, 2005, Landais, 2008). In the case of Ecuador, Cano (2015) reports average persistence rates of $70 \%$ and $60 \%$ for the top $1 \%$ and top $0.1 \%$ respectively.

It is noteworthy that decreasing rates for tinier top fractiles may not necessarily indicate 
Figure 7: Persistence rates in top income fractiles

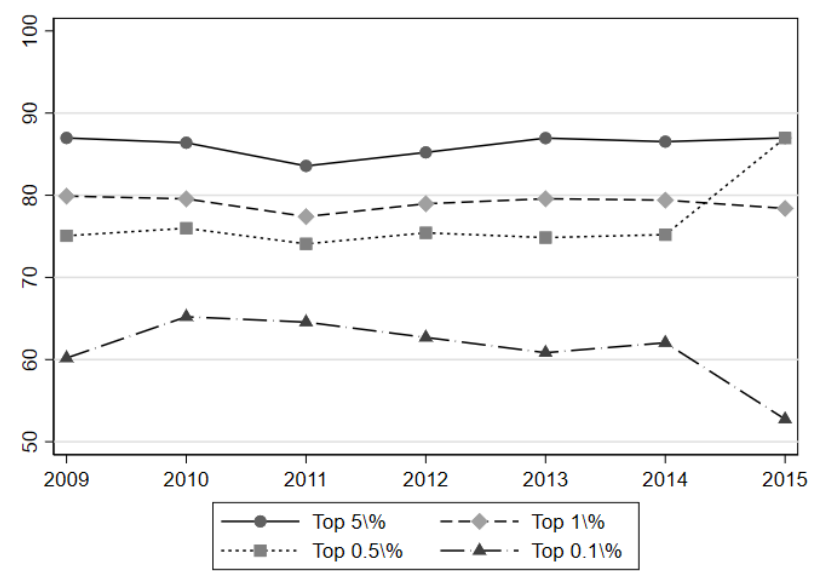

(a) Persistence after 1 year

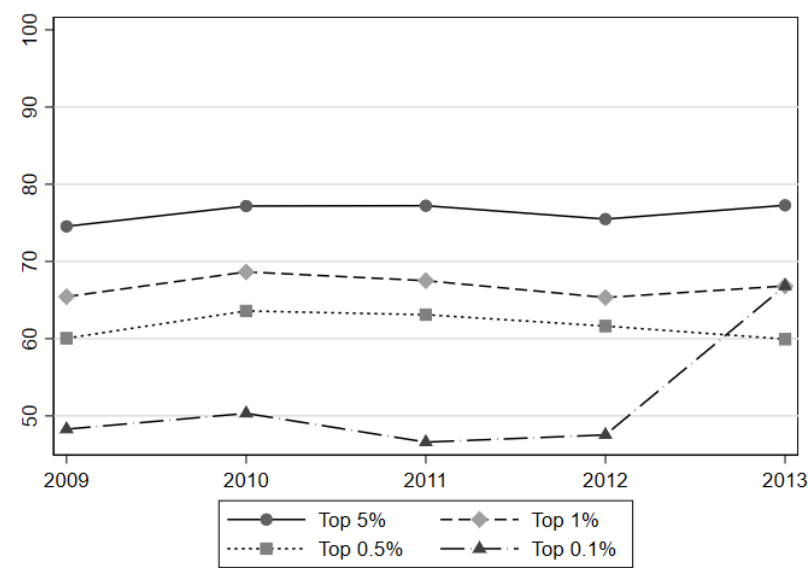

(b) Persistence after 3 years

Note. Own calculations based on tax records (DGI). Persistence rates by income fractile after one and three years depicted in panels (a) and (b) respectively. Persistence rates after three years is unconditional on the position held after one and two years. By construction, the larger the group the more likely is that individuals stay in the same group.

lower persistence in income positions at the very top (Jenderny $(\overline{2016}))$. Furthermore, they may also be resulting from a mechanic effect related to different group size. To account for this problem and compare equal-size groups, we computed 2009 total income deciles restricted for the top $1 \%, 0.5 \%$ and $0.1 \%$, respectively. Figure A.5 plots the fraction of individuals who do not move downward between 2009 and 2016. Similarly to Jenderny $(2016)$, the fraction appears to be increasing with the position in the initial distribution within each fractile: individuals belonging to the richest deciles are less likely to move downwards than the remaining fractile members.

\subsubsection{Distributive effects of income mobility}

Finally, we analyze whether income mobility contributes to reduce long-term income concentration. If annual income partly reflects transitory shocks and relative positions are held by different individuals, we would expect to observe lower income inequality when income is measured over a longer period. Hence, we compare top income shares and inequality indices (Gini y Theil) for the annual and longitudinally-averaged income of each individual (Table 11).

The extent of top income mobility appears to be quite modest: a reduction of 0.3 and 0.6 percentage points in the top $1 \%$ and top $0.1 \%$ income share respectively. Overall, the equalizing effect of income mobility is limited: a reduction of 2.3 p.p. in the Gini coefficient and 6 p.p. in the Theil index. In this case, there are not substantial differences by sub-period. 
Table 11: Annual and average income inequality comparison

\begin{tabular}{l|ccc|ccc|ccc}
\hline & \multicolumn{3}{|c|}{$2009-2016$} & \multicolumn{3}{c|}{$2009-2013$} & \multicolumn{3}{c}{$2013-2016$} \\
\hline & Annual & Permanent & Dif (\%) & Annual & Permanent & Dif (\%) & Annual & Permanent & Dif (\%) \\
\hline Bot.50\% & 0.159 & 0.172 & $-7.6 \%$ & 0.155 & 0.161 & $-3.7 \%$ & 0.165 & 0.170 & $-2.9 \%$ \\
$50 \%-90 \%$ & 0.445 & 0.445 & $-0.2 \%$ & 0.445 & 0.444 & $0.2 \%$ & 0.445 & 0.444 & $0.2 \%$ \\
Top 10\% & 0.120 & 0.118 & $1.4 \%$ & 0.121 & 0.121 & $0.1 \%$ & 0.117 & 0.117 & $0.6 \%$ \\
Top 5\% & 0.155 & 0.152 & $1.8 \%$ & 0.157 & 0.157 & $0.2 \%$ & 0.151 & 0.151 & $0.3 \%$ \\
Top 1\% & 0.079 & 0.076 & $4.5 \%$ & 0.079 & 0.078 & $1.9 \%$ & 0.079 & 0.078 & $0.5 \%$ \\
Top 0.1\% & 0.043 & 0.037 & $16.2 \%$ & 0.043 & 0.040 & $7.7 \%$ & 0.043 & 0.040 & $6.4 \%$ \\
\hline Gini & 0.523 & 0.502 & $4.2 \%$ & 0.529 & 0.519 & $1.8 \%$ & 0.514 & 0.506 & $1.5 \%$ \\
Theil & 0.600 & 0.539 & $11.2 \%$ & 0.612 & 0.584 & $4.8 \%$ & 0.576 & 0.552 & $4.3 \%$ \\
\hline
\end{tabular}

Note. Own calculations based on tax records (DGI). In each block, a different set of base/end years. Within each block, income shares (first panel) and inequality indices (second panel) are depicted in two ways: the average index of the period (annual, first column), and the index of the average income of the period (permanent, second column). The third column of each block depicts the difference between the two, as a percentage of the annual estimate.

These results are not surprising considering the high ranking correlations and persistence rates presented in the previous sub-sections. The slight decrease in rank correlations that accompanied the inequality reduction period was not enough to affect long run redistribution. Thus, in the Uruguayan case, relative distances among individuals were shortened but income increases were not enough to carry out a substantial change in positions held at the beginning of the period.

\section{$5 \quad$ Final remarks}

As in most Latin American countries, previous studies assessing per capita household income from ECH have shown that Uruguay underwent a substantial inequality fall in recent years, coupled with outstanding economic growth. However, analyses for other Latin American countries assessing top income shares present a conflicting picture and cast doubts on the depth and breadth of the inequality fall. The discussion on the "actual" inequality trends is relevant in terms of appraising the relation among economic growth and redistribution as well as the equalizing effect of redistributive policies such as income taxation, changes in wage-setting institutions and non contributory cash transfer schemes.

To address this issue, we estimate primary income inequality and mobility patterns among the adult population aged 20 and more based on personal income tax records micro-data (DGI) and comparable survey micro-data (ECH). Differently to previous studies, we had access to taxrecords micro-data for a substantial fraction of the adult population, that allowed to carry out both synthetic indices and top income shares comparisons. Although levels are substantially higher at DGI micro-data, we found that synthetic indices calculated on the two databases experienced a statistically significant reduction (although milder in DGI tax-records) in the period 2009-2013 and 
remained stable after that. At the same time, the income share accrued by the top $1 \%$ remained stable or even grew in tax micro-data whereas it fell according to ECH based calculations.

A closer look at the percentile thresholds in the two databases shows that until the top $10 \%$, ECH captures primary income correctly with a $90 \%$ ECH to DGI ratio. However, the lower limit and average income of the upper $1 \% \mathrm{ECH} / \mathrm{DGI}$ ratios have been falling throughout the whole period, which might be consistent with underreporting rates and refusal rates growth in $\mathrm{ECH}$ as a rapid income increase was taking place. Additionally, at DGI data the income source composition of the top strata presents a growing share of capital income, consistent with the worsening of ECH outreach at the top. Furthermore, between group inequality decompositions singling out the bottom $99 \%$ (as a whole or by sub-groups) and the top 1\%, suggest that the findings reported in the previous paragraphs are consistent with the patterns of inequality decrease in each data-source.

In fact, whereas in ECH higher income strata experienced higher equalisation levels and led the downwards trend observed in 2009-2013, the inequality reduction at DGI resulted from the low and middle strata (notably the 50-90\%) overcompensating a trend towards increased inequality throughout the whole period at the top. By the end, the inequality reduction at the bottom $99 \%$ could not offset the increase at the top. Unlike in DGI data, at ECH the inequality reduction was higher at the top than at the bottom $99 \%$. The substantial inequality reduction observed at the top (33\% across the whole period) is consistent with its impoverished capacity to reach the more well-off households.

The apparent contradiction between the stability of top income shares and the evolution of Gini and Theil indices calls into discussion several issues related to what kind of inequality is sought to reduce, and broader topics such as the relevance of analysing socio-economic stratification on the basis of a wider scope of variables. It also puts forward the relevance of monitoring and renewing the ways in which household surveys gather information and the need to articulate this information with other valuable data-sources such as tax data.

The longitudinal nature of DGI data also allowed to provide a more complete assessment of economic disparities by analyzing absolute and relative income mobility. Our findings indicate high persistence rates along the income distribution and, particularly among those who hold top income positions. For example, in line with Jenderny (2016) findings for Germany, the average probability of staying at the top $1 \%$ in the next year is around $80 \%$. Results show that periods with slightly lowered persistence rates coincide with decreasing inequality trends. However, our findings also suggest that over the eight years considered, income mobility has very meagre equalizing effects. Thus, annual cross-sectional inequality measures are a good approximation to long run inequality.

The interplay and directional effect of inequality and mobility needs to explored in further research. On the one hand, our results might be reflecting that the equalization process shortened relative distances along individuals but it lacked of the necessary strength to promote a substantial re-ranking. On the other, if the departing point was one of high inequality, it is unlikely that increased absolute mobility (as reflected in absolute rankings) can result in substantial re-ranking. 


\section{References}

Aaberge, R., Atkinson, A. B., and Modalsli, J. (2013). The ins and outs of top income mobility. IZA Discussion Paper 7r29.

Aaberge, R. and Mogstad, M. (2015). Inequality in current and lifetime income. Social Choice and Welfare, 44(2):217-230.

Altimir, O. (1987). Income distribution statistics in latin america and their reliability. Review of income and wealth, 33(2):111-155.

Alvaredo, F. (2010). The rich in Argentina over the twentieth century, 1932-2004. Atkinson A., Piketty T. and Saez E.(eds.)Top incomes: A Global Perspective. Oxford, Oxford University Press, 2.

Alvaredo, F. (2011). A note on the relationship between top income shares and the gini coefficient. Economics Letters, 110(3):274-277.

Alvaredo, F., Atkinson, A., Chancel, L., Piketty, T., Saez, E., Zucman, G., et al. (2016). Distributional National Accounts (DINA) guidelines: Concepts and methods used in wid. world. WID. world Working Paper, 2.

Alvaredo, F., Atkinson, A. B., Piketty, T., and Saez, E. (2013). The top 1 percent in international and historical perspective. Journal of Economic Perspectives, 27(3):3-20.

Alvaredo, F. and Gasparini, L. (2015). Recent trends in inequality and poverty in developing countries. In Atkinson A. and Bourguignon F. (eds.)Handbook of income distribution, volume 2, pages 697-805. Elsevier.

Alvaredo, F. and Londoño Velez, J. (2014). High income and income tax in Colombia, 1993-2010. Revista de Economía Institucional, 16(31):157-194.

Amarante, V., Arim, R., and Salas, G. (2007). Impacto distributivo de la reforma impositiva. background paper for poverty and social impact analysis (psia) of Uruguay.

Amarante, V. and Carella, A. (1997). La captación del ingreso en las encuestas de hogares. Informe proyecto CSIC de iniciación a la investigación.

Amarante, V., Colafranceschi, M., and Vigorito, A. (2014). Uruguay's Income Inequality and Political Regimes over the Period 1981-2010. Cornia A. (ed.) Falling Inequality in Latin America. Policy Changes and Lessons, WIDER Studies in Development Economics. Oxford University Press.

Anand, S. and Segal, P. (2017). Who are the global top 1\%? World Development, 95:111-126. 
Atkinson, A. B. (2007). Measuring top incomes: methodological issues. Top incomes over the twentieth century: A contrast between continental European and English-speaking countries, $1: 18-42$.

Atkinson, A. B., Casarico, A., and Voitchovsky, S. (2018). Top incomes and the gender divide. The Journal of Economic Inequality, 16(2):225-256.

Atkinson, A. B., Piketty, T., and Saez, E. (2011). Top incomes in the long run of history. Journal of economic literature, 49(1):3-71.

Auten, G., Gee, G., and Turner, N. (2013). Income inequality, mobility, and turnover at the top in the us, 1987-2010. American Economic Review, 103(3):168-72.

Barros, R. P. d. O., Foguel, M. N. O., and Ulyssea, G. O. (2006). Desigualdade de renda no brasil: uma análise da queda recente.

Bergolo, M., Burdin, G., De Rosa, M., Giaccobasso, M., Leites, M., and Rueda, H. (2019). Earnings responses of top labor incomes to tax changes: Evidence from a tax reform in uruguay.

Blanchet, T., Flores, I., and Morgan, M. (2018). The weight of the rich: Improving surveys using tax data. WID. world Working Paper, 12.

Bourguignon, F. (2015). Appraising income inequality databases in latin america. The Journal of Economic Inequality, 13(4):557-578.

Bucheli, M., Lustig, N., Rossi, M., and Amábile, F. (2013). Social spending, taxes and income redistribution in Uruguay. The World Bank.

Burdín, G., De Rosa, M., and Vigorito, A. (2015). Sectores de altos ingresos en Uruguay: participación relativa y patrones de movilidad en el período 2009-2012. Serie Documentos de Trabajo; $03 / 15$.

Burdín, G., Esponda, F., and Vigorito, A. (2014a). Desigualdad y altas rentas en el Uruguay: un análisis basado en los registros tributarios y las encuestas de hogares del período 2009-2011. Jiménez J.P. (ed.) Desigualdad, concentración del ingreso y tributación sobre las altas rentas en América Latina, CEPAL. Santiago de Chile., 1.

Burdín, G., Esponda, F., and Vigorito, A. (2014b). Inequality and top incomes in Uruguay: a comparison between household surveys and income tax micro-data. World Top Incomes Database Working Paper, 1.

Burkhauser, R. V., Feng, S., Jenkins, S. P., and Larrimore, J. (2012). Recent trends in top income shares in the United States: reconciling estimates from march cps and irs tax return data. Review of Economics and Statistics, 94(2):371-388. 
Cano, L. (2015). Income mobility in Ecuador: New evidence from individual income tax returns. Technical report, WIDER Working Paper.

Cornia, G. A. (2014). Falling inequality in Latin America: policy changes and lessons. OUP Oxford.

Cowell, F. A. and Flachaire, E. (2015). Statistical methods for distributional analysis. In Handbook of income distribution, volume 2, pages 359-465. Elsevier.

De Rosa, M., Sinisclachi, S., Vilá, J., Vigorito, A., and Willebald, H. (2018). La evolución de las remuneraciones laborales y la distribución del ingreso en Uruguay; futuro en foco. Cuadernos Sobre Desarrollo Humano: Montevideo, Uruguay.

De Rosa, M. and Vilá, J. (2017). Distributional National Accounts for Uruguay 2009-2014: Fallin inequality through the lens of DINA.

Fairfield, T. and Jorratt De Luis, M. (2016). Top income shares, business profits, and effective tax rates in contemporary c hile. Review of Income and Wealth, 62:S120-S144.

Feenberg, D. R. and Poterba, J. M. (1993). Income inequality and the incomes of very high-income taxpayers: evidence from tax returns. Tax policy and the economy, 7:145-177.

Fields, G. S. and Ok, E. A. (1999). The measurement of income mobility: an introduction to the literature. In Handbook of income inequality measurement, pages 557-598. Springer.

Flores, I., Sanhueza, C., Atria, J., and Mayer, R. (2019). Top incomes in chile: A historical perspective on income inequality, 1964-2017. Review of Income and Wealth.

Gasparini, L., Bracco, J., Galeano, L., and Pistorio, M. (2018). Desigualdad en países en desarrollo: ¿ajustando las expectativas? Documentos de Trabajo del CEDLAS.

Groskoff, R. (1992). Análisis y ajuste de los ingresos investigados por las encuestas de hogares. Documento de Trabajo.

Higgins, S., Lustig, N., and Vigorito, A. (2018). The rich underreport their income: Assessing bias in inequality estimates and correction methods using linked survey and tax data.

Jenderny, K. (2016). Mobility of top incomes in g ermany. Review of Income and Wealth, 62(2):245265.

Jenkins, S. P. (2015). World income inequality databases: an assessment of wiid and swiid. The Journal of Economic Inequality, 13(4):629-671.

Joumard, I., Pisu, M., and Bloch, D. (2013). Tackling income inequality. OECD Journal: Economic Studies, 2012(1):37-70. 
Kopczuk, W., Saez, E., and Song, J. (2007). Uncovering the american dream: Inequality and mobility in social security earnings data since 1937. Technical report, National Bureau of Economic Research.

Kopczuk, W., Saez, E., and Song, J. (2010). Earnings inequality and mobility in the united states: evidence from social security data since 1937. The Quarterly Journal of Economics, 125(1):91-128.

Landais, C. (2008). Top incomes in France: booming inequalities? Paris School of Economics, Mimeo.

Leigh, A. (2007). How closely do top income shares track other measures of inequality? The Economic Journal, 117(524):F619-F633.

Lerman, R. I. and Yitzhaki, S. (1985). Income inequality effects by income source: A new approach and applications to the united states. The review of economics and statistics, pages 151-156.

López, R., Figueroa, E., Gutiérrez, P., et al. (2013). La 'parte del león': Nuevas estimaciones de la participación de los súper ricos en el ingreso de chile. Serie Documentos de Trabajo, 379:1-32.

Lustig, N. et al. (2019). The missing rich in household surveys: Causes and correction approaches. Technical report, Tulane University, Department of Economics.

Lustig, N., López-Calva, L. F., and Ortiz-Juarez, E. (2011). The decline in inequality in latin america: How much, since when and why. Since When and Why (April 24, 2011).

Mendive, C. and Fuentes, A. (1996). Diferencias en la captación del ingreso por fuente" en ine. Taller de expertos sobre medición de pobreza.

Morgan, M. (2017). Extreme and persistent inequality: New evidence for Brazil combining national accounts, surveys and fiscal data, 2001-2015. World Inequality Database (WID. org) Working Paper Series, 12:1-50.

Piketty, T. (2003). Income inequality in France, 1901-1998. Journal of political economy, 111(5):1004-1042.

Piketty, T., Yang, L., and Zucman, G. (2017). Capital accumulation, private property and rising inequality in china, 1978-2015. National Bureau of Economic Research.

Rodríguez Vivas, M. (2019). Segregación residencial en montevideo: su evolución por variables estructurales para el período 2006-2017. Technical report, Instituto de Economía, Facultad de Ciencias Econǿmicas y Administración, Universidad de la República, Uruguay. 
Saez, E. and Veall, M. R. (2005). The evolution of high incomes in northern america: lessons from canadian evidence. American Economic Review, 95(3):831-849.

Shorrocks, A. F. (1978). The measurement of mobility. Econometrica: Journal of the Econometric Society, pages 1013-1024.

Shorrocks, A. F. (1981). Income stability in the United States. In The statics and dynamics of income. Citeseer.

Shorrocks, A. F. (1999). Decomposition procedures for distributional analysis: a unified framework based on the shapley value. Technical report, mimeo, University of Essex.

Souza, P. H. and Medeiros, M. (2015). Top income shares and inequality in brazil, 1928-2012. Sociologies in Dialogue, 1(1).

Székely, M. and Hilgert, M. (1999). What's behind the inequality we measure? an investigation using latin american data. An Investigation Using Latin American Data (December 1999). IDB-OCE Working Paper, (409).

Tornarolli, L., Ciaschi, M., and Galeano, L. (2018). Income distribution in latin america: The evolution in the last 20 years: A global approach. Documentos de Trabajo del CEDLAS. 


\section{A Appendix}

Table A.1: Capital incomes tax rates

\begin{tabular}{lc}
\hline Income capital & Tax rate \\
\hline Interests corresponding to bank deposits in Uruguayan currency more & $3 \%$ \\
than one year lenght and debt titles interests-3 years or more & \\
Interests corresponding to bank deposits in Uruguayan currency less & $5 \%$ \\
than one year lenght & $7 \%$ \\
Dividends and utilities & $12 \%$ \\
Housing and mobiliary capital rents & $12 \%$ \\
Others rents (sportpersons royalties, author royalties, everlasting & \\
rents) & \\
\hline
\end{tabular}

Note. Own elaboration based on DGI (2019).

Table A.2: Labor income tax rates

\begin{tabular}{lc|lc}
\hline Income bracket (BPC) & Tax 2009-2011 & Income bracket (BPC) & Tax rate 2012-2016 \\
\hline $0-84$ & 0 & $0-84$ & 0 \\
$84-120$ & 10 & $84-120$ & 10 \\
$120-180$ & 15 & $120-180$ & 15 \\
$180-600$ & 20 & $180-600$ & 20 \\
$600-1200$ & 22 & $600-900$ & 22 \\
$>1200$ & 25 & $900-1380$ & 25 \\
& & $>1380$ & 30 \\
\hline
\end{tabular}

Note. Own elaboration based on DGI (2019). 
Table A.3: Pensions tax rates

\begin{tabular}{lc}
\hline Pension income bracket $(\mathrm{BPC})$ & Tax rate \\
\hline $0-96$ & 0 \\
$96-180$ & 10 \\
$180-600$ & 20 \\
$>600$ & 25 \\
\hline
\end{tabular}

Note. Own elaboration based on DGI (2019).

Table A.4: Income threshold by fractile, 2009-2016

\begin{tabular}{lcccccccc}
\hline & 2009 & 2010 & 2011 & 2012 & 2013 & 2014 & 2015 & 2016 \\
\hline Mean & 7,711 & 9,885 & 11,727 & 12,925 & 14,465 & 14,519 & 13,717 & 14,115 \\
\hline P50 & 4,173 & 5,401 & 6,611 & 7,296 & 8,449 & 8,574 & 8,166 & 8,315 \\
P90 & 16,639 & 21,137 & 24,534 & 27,107 & 29,845 & 29,826 & 27,693 & 28,229 \\
P99 & 51,488 & 64,990 & 75,889 & 83,947 & 90,048 & 90,614 & 85,670 & 89,084 \\
P995 & 71,273 & 89,879 & 104,658 & 115,418 & 124,411 & 127,750 & 120,874 & 129,563 \\
P999 & 152,646 & 195,161 & 234,337 & 249,884 & 276,572 & 284,969 & 279,407 & 323,495 \\
P9995 & 214,476 & 280,035 & 335,945 & 352,553 & 382,714 & 404,714 & 407,687 & 483,031 \\
P9999 & 509,210 & 636,527 & 795,509 & 888,552 & $1,014,507$ & $1,080,096$ & $1,144,089$ & $1,427,661$ \\
\hline Mean top 0001 & $1,504,618$ & $2,030,844$ & $2,919,147$ & $2,879,033$ & $3,730,341$ & $3,149,241$ & $3,465,832$ & $3,569,248$ \\
\hline
\end{tabular}

Note. Own elaboration based on tax records (DGI). 
Table A.5: Number of taxpayers by income source

\begin{tabular}{ll|cccccccc}
\hline & & 2009 & 2010 & 2011 & 2012 & 2013 & 2014 & 2015 & 2016 \\
\hline \multirow{3}{*}{ Labor income } & Total & $1,187,913$ & $1,183,629$ & $1,237,034$ & $1,222,505$ & $1,272,881$ & $1,297,408$ & $1,313,961$ & $1,310,285$ \\
& Taxpayers & 315,300 & 347,001 & 395,207 & 416,318 & 471,838 & 510,567 & 753,705 & 770,127 \\
& Total & $1,127,943$ & $1,111,782$ & $1,161,260$ & $1,143,757$ & $1,190,855$ & $1,216,827$ & $1,253,834$ & $1,237,214$ \\
& Taxpayers & 276,664 & 300,461 & 345,480 & 363,546 & 416,530 & 454,957 & 706,868 & 715,150 \\
\multirow{3}{*}{ Self employed } & Total & 51,024 & 53,489 & 55,676 & 54,958 & 57,956 & 57,998 & 40,509 & 51,705 \\
& Taxpayers & 28,760 & 30,405 & 31,823 & 31,684 & 33,653 & 34,957 & 36,533 & 44,843 \\
\hline \multirow{3}{*}{ Irae } & Total & 3,504 & 3,607 & 3,687 & 3,899 & 4,016 & 4,128 & 3,970 & 4,338 \\
\multirow{3}{*}{ Pensions } & Taxpayers & 3,173 & 3,253 & 3,348 & 3,503 & 3,619 & 3,676 & 3,516 & 3,826 \\
& Total & 639,540 & 661,366 & 627,764 & 684,320 & 690,830 & 698,594 & 709,216 & 715,801 \\
& Taxpayers & 102,136 & 112,445 & 111,787 & 137,988 & 148,749 & 158,991 & 170,184 & 173,867 \\
\hline \multirow{2}{*}{ Capital } & Total & 261,765 & 298,431 & 323,035 & 390,660 & 445,263 & 385,352 & 586,851 & 656,789 \\
& Taxpayers & 255,697 & 293,041 & 318,012 & 386,745 & 441,457 & 380,569 & 582,905 & 652,258 \\
\multirow{2}{*}{ Dividends } & Total & 3,134 & 3,437 & 4,539 & 5,297 & 5,933 & 6,752 & 8,473 & 9,339 \\
& Taxpayers & 3,134 & 3,437 & 4,539 & 5,297 & 5,933 & 6,752 & 8,473 & 9,339 \\
\multirow{2}{*}{ Real state rents } & Total & 55,205 & 55,089 & 57,759 & 58,600 & 61,102 & 66,076 & 70,032 & 73,771 \\
& Taxpayers & 50,829 & 50,711 & 54,800 & 57,212 & 59,969 & 65,028 & 69,196 & 72,905 \\
\hline
\end{tabular}

Note. Own elaboration based on tax records (DGI). 
Table A.6: Non nominative capital incomes as a share of total capital incomes

\begin{tabular}{|c|c|c|c|c|c|c|c|c|}
\hline \multicolumn{9}{|c|}{ Total } \\
\hline & 2009 & 2010 & 2011 & 2012 & 2013 & 2014 & 2015 & 2016 \\
\hline $\begin{array}{l}\text { Interests corresponding } \\
\text { to bank deposits in } \\
\text { Uruguayan currency or } \\
\text { UI, more than one year } \\
\text { lengh in local financial } \\
\text { institutions }\end{array}$ & $99,8 \%$ & $100,0 \%$ & $97,5 \%$ & $100,0 \%$ & $100,0 \%$ & $100,0 \%$ & $100,0 \%$ & $100,0 \%$ \\
\hline $\begin{array}{l}\text { Interests for bank } \\
\text { deposits to one year or }\end{array}$ & & & & & & & & \\
\hline $\begin{array}{l}\text { more, in Uruguayan } \\
\text { currency with no } \\
\text { indexation clause }\end{array}$ & $99,9 \%$ & $100,0 \%$ & $98,3 \%$ & $100,0 \%$ & $100,0 \%$ & $100,0 \%$ & $100,0 \%$ & $100,0 \%$ \\
\hline $\begin{array}{l}\text { Obligations and other } \\
\text { debt titles interests-3 } \\
\text { years or more }\end{array}$ & $41,2 \%$ & $34,2 \%$ & $48,1 \%$ & $96,2 \%$ & $74,6 \%$ & $97,6 \%$ & $91,1 \%$ & $79,6 \%$ \\
\hline $\begin{array}{l}\text { Remaining financial } \\
\text { and mobiliary capital } \\
\text { rents }\end{array}$ & $62,9 \%$ & $52,2 \%$ & $47,4 \%$ & $59,2 \%$ & $54,4 \%$ & $44,3 \%$ & $49,1 \%$ & $48,1 \%$ \\
\hline $\begin{array}{l}\text { Dividends and } \\
\text { utilities }\end{array}$ & $31,3 \%$ & $39,3 \%$ & $42,7 \%$ & $47,2 \%$ & $38,7 \%$ & $39,3 \%$ & $36,9 \%$ & $34,6 \%$ \\
\hline $\begin{array}{l}\text { Sportpersons } \\
\text { royalties }\end{array}$ & $10,4 \%$ & $2,5 \%$ & $54,0 \%$ & $8,8 \%$ & $13,4 \%$ & $-11,8 \%$ & $0,9 \%$ & $-4,4 \%$ \\
\hline Author royalties & $-73,0 \%$ & $-73,7 \%$ & $-51,8 \%$ & $-70,0 \%$ & $-63,0 \%$ & $-62,4 \%$ & $-64,3 \%$ & $-64,3 \%$ \\
\hline
\end{tabular}

Note. Own elaboration based on tax records (DGI).

Table A.7: Owners' withdrawals - added individuals, 2009-2016

\begin{tabular}{c|cc|cc|cc}
\hline Year & $\begin{array}{c}\text { Withdrawing } \\
\text { profits }\end{array}$ & $\begin{array}{c}\text { Top-labour } \\
\text { income earners }\end{array}$ & $\begin{array}{c}\text { Additional } \\
\text { individuals }\end{array}$ & $\begin{array}{c}\text { Additional individuals } \\
\text { \% tax records) }\end{array}$ & $\begin{array}{c}\text { Tax } \\
\text { record }\end{array}$ & $\begin{array}{c}\text { Survey } \\
\text { population }\end{array}$ \\
\hline 2009 & 1070 & 3284 & 1552 & $0.09 \%$ & 1721207 & 759168 \\
2010 & 1611 & 2747 & 1034 & $0.06 \%$ & 1722902 & 742245 \\
2011 & 2150 & 3015 & 1350 & $0.08 \%$ & 1758779 & 696426 \\
2012 & 2280 & 3291 & 1390 & $0.08 \%$ & 1793012 & 686455 \\
2013 & 2975 & 3470 & 1435 & $0.08 \%$ & 1852341 & 685052 \\
2014 & 3430 & 3800 & 1611 & $0.08 \%$ & 1928833 & 674913 \\
2015 & 5107 & 4183 & 1865 & $0.10 \%$ & 1916230 & 690735 \\
2016 & 6448 & 5002 & 2202 & $0.11 \%$ & 1923850 & 707894 \\
\hline
\end{tabular}

Note. Own elaboration based on tax records (DGI). 


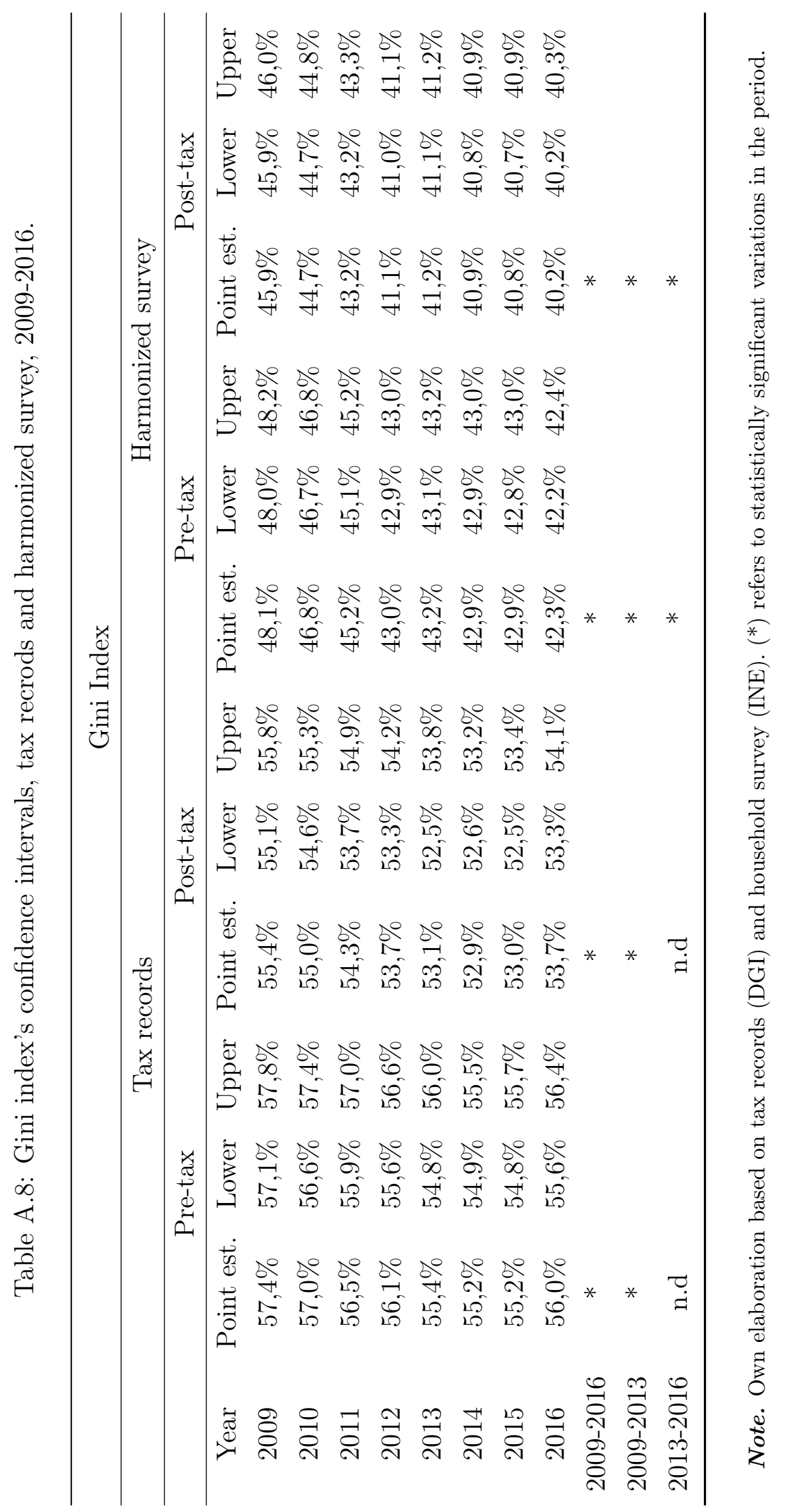


Table A.9: Inequality indices, pre and post-tax, by source, 2009-2016

\begin{tabular}{c|cccc|cccc}
\hline & \multicolumn{3}{c|}{ Gini Index } & \multicolumn{4}{c}{ Theil Index } \\
\hline \multirow{2}{*}{ Year } & \multicolumn{2}{|c}{ Tax records } & \multicolumn{3}{c}{ Harmonized survey } & \multicolumn{2}{|c}{ Tax records } & \multicolumn{2}{c}{ Harmonized survey } \\
& Pre-tax & Post-tax & Pre-tax & Post-tax & Pre-tax & Post-tax & Pre-tax & Post-tax \\
\hline 2009 & 0.574 & 0.554 & 0.481 & 0.459 & 0.712 & 0.638 & 0.451 & 0.401 \\
2010 & 0.570 & 0.550 & 0.468 & 0.447 & 0.710 & 0.635 & 0.409 & 0.366 \\
2011 & 0.565 & 0.543 & 0.452 & 0.432 & 0.730 & 0.658 & 0.375 & 0.336 \\
2012 & 0.561 & 0.537 & 0.430 & 0.411 & 0.709 & 0.611 & 0.319 & 0.288 \\
2013 & 0.554 & 0.531 & 0.432 & 0.412 & 0.711 & 0.638 & 0.331 & 0.296 \\
2014 & 0.552 & 0.529 & 0.429 & 0.409 & 0.676 & 0.606 & 0.329 & 0.293 \\
2015 & 0.552 & 0.530 & 0.429 & 0.408 & 0.706 & 0.637 & 0.338 & 0.299 \\
2016 & 0.560 & 0.537 & 0.423 & 0.402 & 0.734 & 0.663 & 0.320 & 0.284 \\
\hline
\end{tabular}

Note. Own calculations based on household survey (INE) and tax records (DGI). 
Table A.10: Inequality decomposition among income groups, 2009-2016.

\begin{tabular}{|c|c|c|c|c|c|c|c|c|}
\hline & 2009 & 2010 & 2011 & 2012 & 2013 & 2014 & 2015 & 2016 \\
\hline & \multicolumn{8}{|c|}{ Tax records (DGI) } \\
\hline Gini index & 0,574 & 0,570 & 0,565 & 0,561 & 0,554 & 0,552 & 0,552 & 0,560 \\
\hline Between & 0,510 & 0,506 & 0,502 & 0,498 & 0,492 & 0,490 & 0,491 & 0,499 \\
\hline Within & 0,065 & 0,064 & 0,063 & 0,063 & 0,062 & 0,062 & 0,061 & 0,061 \\
\hline Overlap & 0,000 & 0,000 & 0,000 & 0,000 & 0,000 & 0,000 & 0,000 & 0,000 \\
\hline Between (\%) & 88,8 & 88,8 & 88,9 & 88,9 & 88,8 & 88,8 & 88,9 & 89,1 \\
\hline Within (\%) & 11,2 & 11,2 & 11,1 & 11,1 & 11,2 & 11,2 & 11,1 & 10,9 \\
\hline Overlap (\%) & 0,0 & 0,0 & 0,0 & 0,0 & 0,0 & 0,0 & 0,0 & 0,0 \\
\hline Bottom 50 & 0,328 & 0,323 & 0,321 & 0,312 & 0,314 & 0,316 & 0,317 & 0,322 \\
\hline $50-90$ & 0,219 & 0,215 & 0,208 & 0,207 & 0,198 & 0,196 & 0,193 & 0,193 \\
\hline $90-99$ & 0,173 & 0,172 & 0,172 & 0,170 & 0,168 & 0,169 & 0,172 & 0,173 \\
\hline \multirow[t]{2}{*}{ Top 1\% } & 0,355 & 0,364 & 0,390 & 0,383 & 0,400 & 0,385 & 0,408 & 0,423 \\
\hline & \multicolumn{8}{|c|}{ Harmonized survey $(\mathrm{ECH})$} \\
\hline Gini index & 0,481 & 0,468 & 0,452 & 0,430 & 0,431 & 0,429 & 0,429 & 0,423 \\
\hline Between & 0,421 & 0,409 & 0,393 & 0,369 & 0,373 & 0,371 & 0,371 & 0,365 \\
\hline Within & 0,059 & 0,059 & 0,059 & 0,060 & 0,059 & 0,059 & 0,058 & 0,058 \\
\hline Overlap & 0,000 & 0,000 & 0,000 & 0,000 & 0,000 & 0,000 & 0,000 & 0,000 \\
\hline Between (\%) & 87,6 & 87,4 & 86,9 & 86,0 & 86,4 & 86,4 & 86,5 & 86,3 \\
\hline Within (\%) & 12,4 & 12,6 & 13,1 & 14,0 & 13,6 & 13,6 & 13,5 & 13,7 \\
\hline Overlap (\%) & 0,0 & 0,0 & 0,0 & 0,0 & 0,0 & 0,0 & 0,0 & 0,0 \\
\hline Bottom 50 & 0,257 & 0,248 & 0,249 & 0,246 & 0,238 & 0,241 & 0,241 & 0,240 \\
\hline $50-90$ & 0,175 & 0,172 & 0,166 & 0,163 & 0,161 & 0,158 & 0,156 & 0,152 \\
\hline $90-99$ & 0,155 & 0,154 & 0,143 & 0,128 & 0,134 & 0,136 & 0,137 & 0,137 \\
\hline Top 1\% & 0,260 & 0,214 & 0,199 & 0,127 & 0,174 & 0,177 & 0,188 & 0,171 \\
\hline
\end{tabular}

Note. Own calculations based on tax records (DGI) and household surveys (ECH). The table is divided in two panels, depicting tax records and harmonized surveys respectively. By construction, both micro-data bases refer to the same individuals and same incomes (pre-tax and formal total personal incomes). In each panel, Gini index is decomposed in between and within components, among the groups defined. 
Table A.11: Pre-tax distribution by source and fractile, 2009, 2013, 2016.

\begin{tabular}{|c|c|c|c|c|c|c|c|}
\hline & $\begin{array}{l}\text { Labor } \\
\text { income }\end{array}$ & Pensions & $\begin{array}{l}\text { Mixed } \\
\text { income }\end{array}$ & $\begin{array}{l}\text { Capital } \\
\text { income }\end{array}$ & Dividends & Rents & Others \\
\hline & \multicolumn{7}{|c|}{2009} \\
\hline Bot. $50 \%$ & $53,6 \%$ & $45,0 \%$ & $0,0 \%$ & $1,3 \%$ & $0,0 \%$ & $1,0 \%$ & $0,2 \%$ \\
\hline Mid. $40 \%$ & $72,3 \%$ & $25,4 \%$ & $0,1 \%$ & $2,2 \%$ & $0,0 \%$ & $1,4 \%$ & $0,8 \%$ \\
\hline Cent. 90-99 & $76,1 \%$ & $18,1 \%$ & $0,7 \%$ & $5,1 \%$ & $0,3 \%$ & $2,8 \%$ & $2,0 \%$ \\
\hline Top $1 \%$ & $59,4 \%$ & $3,3 \%$ & $6,5 \%$ & $30,8 \%$ & $8,0 \%$ & $8,2 \%$ & $14,4 \%$ \\
\hline Top $0,1 \%$ & $32,3 \%$ & $0,4 \%$ & $7,5 \%$ & $59,8 \%$ & $17,7 \%$ & $14,1 \%$ & $28,1 \%$ \\
\hline \multirow[t]{2}{*}{ Average } & $69,3 \%$ & $22,8 \%$ & $1,1 \%$ & $6,8 \%$ & $1,2 \%$ & $2,7 \%$ & $2,9 \%$ \\
\hline & \multicolumn{7}{|c|}{2013} \\
\hline Bot. $50 \%$ & $50 \%$ & $46,3 \%$ & $0,0 \%$ & $1,8 \%$ & $0,0 \%$ & $1,2 \%$ & $0,6 \%$ \\
\hline Mid. $40 \%$ & $40 \%$ & $22,6 \%$ & $0,1 \%$ & $2,5 \%$ & $0,1 \%$ & $1,3 \%$ & $1,1 \%$ \\
\hline Cent. 90-99 & $75,0 \%$ & $18,6 \%$ & $0,8 \%$ & $5,7 \%$ & $0,9 \%$ & $2,8 \%$ & $2,0 \%$ \\
\hline Top $1 \%$ & $51,3 \%$ & $3,3 \%$ & $6,0 \%$ & $39,4 \%$ & $17,3 \%$ & $8,0 \%$ & $14,2 \%$ \\
\hline Top $0.1 \%$ & $21,8 \%$ & $0,5 \%$ & $5,0 \%$ & $72,7 \%$ & $32,3 \%$ & $12,0 \%$ & $28,4 \%$ \\
\hline \multirow[t]{2}{*}{ Average } & $68,4 \%$ & $22,2 \%$ & $1,1 \%$ & $8,3 \%$ & $2,7 \%$ & $2,6 \%$ & $3,0 \%$ \\
\hline & \multicolumn{7}{|c|}{2016} \\
\hline Bot. $50 \%$ & $50 \%$ & $47,6 \%$ & $0,0 \%$ & $2,0 \%$ & $0,1 \%$ & $1,4 \%$ & $0,5 \%$ \\
\hline Mid. $40 \%$ & $40 \%$ & $22,4 \%$ & $0,1 \%$ & $2,3 \%$ & $0,1 \%$ & $1,5 \%$ & $0,6 \%$ \\
\hline Cent. 90-99 & $74,7 \%$ & $18,3 \%$ & $0,6 \%$ & $6,4 \%$ & $1,3 \%$ & $3,3 \%$ & $1,8 \%$ \\
\hline Top 1\% & $49,4 \%$ & $2,3 \%$ & $5,5 \%$ & $42,8 \%$ & $19,9 \%$ & $7,6 \%$ & $15,2 \%$ \\
\hline Top $0.1 \%$ & $26,3 \%$ & $0,3 \%$ & $5,1 \%$ & $68,3 \%$ & $32,0 \%$ & $8,5 \%$ & $27,8 \%$ \\
\hline Average & $67,7 \%$ & $21,8 \%$ & $1,0 \%$ & $9,5 \%$ & $3,4 \%$ & $2,9 \%$ & $3,1 \%$ \\
\hline
\end{tabular}

Note. Own elaboration based on tax records (DGI). Income composition by income groups is depicted in three panels, which correspond to the years 2009, 2013 and 2016. For each year, bottom 50\%, middle 40\%, top 10\% (excluding top 1\%), top $1 \%$ and top $0.1 \%$ are depicted. By construction, the first four groups of each panel account for the entire population. Total income is disaggregated in labor income, pensions, mixed income and capital income. The latter is turn disaggregated in dividends, rents and other capital incomes. 
Table A.12: Gini index decomposition by income source. Harmonized ECH data.

\begin{tabular}{llllllllll}
\hline & Year & 2009 & 2010 & 2011 & 2012 & 2013 & 2014 & 2015 & 2016 \\
\hline \multirow{2}{*}{ Sk } & Labor inc. & 0.759 & 0.755 & 0.757 & 0.762 & 0.757 & 0.757 & 0.756 & 0.742 \\
& Pensions & 0.209 & 0.214 & 0.216 & 0.214 & 0.217 & 0.217 & 0.219 & 0.233 \\
& Capital inc. & 0.032 & 0.031 & 0.028 & 0.024 & 0.027 & 0.027 & 0.025 & 0.025 \\
\hline \multirow{2}{*}{ Gk } & Labor inc. & 0.642 & 0.633 & 0.623 & 0.613 & 0.607 & 0.607 & 0.612 & 0.614 \\
& Pensions & 0.803 & 0.800 & 0.794 & 0.793 & 0.791 & 0.791 & 0.791 & 0.779 \\
& Capital inc. & 0.981 & 0.980 & 0.978 & 0.980 & 0.978 & 0.978 & 0.979 & 0.977 \\
\hline \multirow{2}{*}{ Rk } & Labor inc. & 0.867 & 0.861 & 0.861 & 0.860 & 0.858 & 0.857 & 0.854 & 0.845 \\
& Pensions & 0.246 & 0.238 & 0.207 & 0.182 & 0.186 & 0.177 & 0.189 & 0.189 \\
& Capital inc. & 0.668 & 0.663 & 0.596 & 0.586 & 0.698 & 0.593 & 0.597 & 0.592 \\
\hline \multirow{2}{*}{ Share } & Labor inc. & 0.872 & 0.871 & 0.887 & 0.900 & 0.912 & 0.896 & 0.894 & 0.887 \\
& Pensions & 0.085 & 0.086 & 0.078 & 0.069 & 0.076 & 0.069 & 0.074 & 0.079 \\
& Capital inc. & 0.043 & 0.043 & 0.035 & 0.031 & 0.013 & 0.035 & 0.032 & 0.034 \\
\hline \multirow{2}{*}{ Change (\%) } & Labor inc. & 0.113 & 0.116 & 0.130 & 0.138 & 0.142 & 0.139 & 0.137 & 0.145 \\
& Pensions & -0.124 & -0.128 & -0.138 & -0.145 & -0.147 & -0.148 & -0.145 & -0.154 \\
& Capital inc. & 0.011 & 0.012 & 0.008 & 0.007 & 0.005 & 0.009 & 0.008 & 0.008 \\
\hline
\end{tabular}

Note. Own elaboration based harmonized household surveys (ECH). Gini index income source decomposition (Lerman and Yitzhaki (1985)) is depicted. $k$ is income source, $S$ is the income share, $G$ is the within source Gini index, $R$ reports the correlation among each income source and total Gini, share represents the contribution of each source to overall inequality and change is the marginal effect of a $1 \%$ increase. 
Table A.13: Entry and exit rates by individuals' characteristics

\begin{tabular}{|c|c|c|c|c|c|c|c|c|c|c|c|c|c|c|}
\hline & \multicolumn{7}{|c|}{ Entries } & \multicolumn{7}{|c|}{ Exits } \\
\hline & 2010 & 2011 & 2012 & 2013 & 2014 & 2015 & 2016 & 2009 & 2010 & 2011 & 2012 & 2013 & 2014 & 2015 \\
\hline Total & $9.9 \%$ & $8.0 \%$ & $6.5 \%$ & $5.7 \%$ & $4.9 \%$ & $4.2 \%$ & $3.8 \%$ & $2.7 \%$ & $3.0 \%$ & $3.4 \%$ & $3.8 \%$ & $4.4 \%$ & $5.8 \%$ & $8.7 \%$ \\
\hline Men & $9.8 \%$ & $7.9 \%$ & $6.4 \%$ & $5.7 \%$ & $4.9 \%$ & $4.2 \%$ & $3.3 \%$ & $2.7 \%$ & $3.0 \%$ & $3.4 \%$ & $4.0 \%$ & $4.7 \%$ & $6.2 \%$ & $9.5 \%$ \\
\hline Women & $10.0 \%$ & $8.0 \%$ & $6.6 \%$ & $5.7 \%$ & $4.9 \%$ & $4.1 \%$ & $3.5 \%$ & $2.7 \%$ & $2.9 \%$ & $3.3 \%$ & $3.6 \%$ & $4.1 \%$ & $5.3 \%$ & $7.7 \%$ \\
\hline$<25$ & $29.7 \%$ & $27.0 \%$ & $24.0 \%$ & $23.1 \%$ & $21.4 \%$ & $19.9 \%$ & $19.0 \%$ & $2.0 \%$ & $2.5 \%$ & $3.4 \%$ & $4.4 \%$ & $6.1 \%$ & $9.8 \%$ & $16.9 \%$ \\
\hline $25-35$ & $10.9 \%$ & $8.0 \%$ & $5.8 \%$ & $4.6 \%$ & $3.7 \%$ & $2.6 \%$ & $1.5 \%$ & $2.1 \%$ & $2.4 \%$ & $3.0 \%$ & $3.8 \%$ & $4.9 \%$ & $7.0 \%$ & $11.3 \%$ \\
\hline $35-45$ & $8.5 \%$ & $6.5 \%$ & $5.1 \%$ & $4.1 \%$ & $3.1 \%$ & $2.3 \%$ & $1.4 \%$ & $2.0 \%$ & $2.2 \%$ & $2.8 \%$ & $3.4 \%$ & $4.2 \%$ & $5.8 \%$ & $9.3 \%$ \\
\hline $45-55$ & $7.0 \%$ & $5.2 \%$ & $4.3 \%$ & $3.5 \%$ & $2.7 \%$ & $2.0 \%$ & $1.5 \%$ & $1.8 \%$ & $2.1 \%$ & $2.5 \%$ & $3.0 \%$ & $3.6 \%$ & $4.8 \%$ & $7.5 \%$ \\
\hline $55-65$ & $7.9 \%$ & $5.2 \%$ & $4.0 \%$ & $3.5 \%$ & $2.7 \%$ & $2.3 \%$ & $1.8 \%$ & $1.7 \%$ & $1.8 \%$ & $2.1 \%$ & $2.1 \%$ & $2.6 \%$ & $3.2 \%$ & $4.5 \%$ \\
\hline$>65$ & $2.9 \%$ & $2.0 \%$ & $1.4 \%$ & $1.4 \%$ & $1.2 \%$ & $1.3 \%$ & $2.3 \%$ & $5.1 \%$ & $5.4 \%$ & $5.1 \%$ & $5.1 \%$ & $4.5 \%$ & $4.6 \%$ & $5.0 \%$ \\
\hline Labor & $12.9 \%$ & $10.4 \%$ & $8.7 \%$ & $7.6 \%$ & $6.5 \%$ & $5.5 \%$ & $4.9 \%$ & $2.0 \%$ & $2.4 \%$ & $3.0 \%$ & $3.7 \%$ & $4.7 \%$ & $6.8 \%$ & $11.1 \%$ \\
\hline Employed $(+1)$ & $3.5 \%$ & $2.6 \%$ & $1.4 \%$ & $1.2 \%$ & $1.2 \%$ & $3.2 \%$ & $3.3 \%$ & $0.6 \%$ & $0.9 \%$ & $1.4 \%$ & $1.0 \%$ & $1.3 \%$ & $2.0 \%$ & $11.3 \%$ \\
\hline Employed & $10.8 \%$ & $8.9 \%$ & $7.1 \%$ & $6.0 \%$ & $5.2 \%$ & $3.3 \%$ & $2.8 \%$ & $1.2 \%$ & $1.4 \%$ & $1.9 \%$ & $2.5 \%$ & $3.5 \%$ & $5.8 \%$ & $9.4 \%$ \\
\hline Self-employed & $14.2 \%$ & $11.5 \%$ & $9.9 \%$ & $8.6 \%$ & $7.3 \%$ & $6.4 \%$ & $5.7 \%$ & $2.3 \%$ & $2.8 \%$ & $3.5 \%$ & $4.3 \%$ & $5.4 \%$ & $7.5 \%$ & $12.1 \%$ \\
\hline Both & $9.0 \%$ & $6.7 \%$ & $4.9 \%$ & $4.2 \%$ & $3.1 \%$ & $5.8 \%$ & $9.1 \%$ & $2.1 \%$ & $2.4 \%$ & $2.6 \%$ & $2.6 \%$ & $3.4 \%$ & $4.2 \%$ & $7.2 \%$ \\
\hline Pensions & $5.0 \%$ & $3.5 \%$ & $2.6 \%$ & $2.4 \%$ & $2.1 \%$ & $2.0 \%$ & $1.8 \%$ & $4.2 \%$ & $4.3 \%$ & $4.2 \%$ & $4.2 \%$ & $3.9 \%$ & $4.0 \%$ & $4.3 \%$ \\
\hline Capital & $5.3 \%$ & $7.0 \%$ & $4.6 \%$ & $3.8 \%$ & $2.8 \%$ & $3.8 \%$ & $8.0 \%$ & $5.8 \%$ & $1.7 \%$ & $2.7 \%$ & $2.9 \%$ & $3.5 \%$ & $2.4 \%$ & $4.4 \%$ \\
\hline
\end{tabular}

Note. Own elaboration based on tax records (DGI). 
Table A.14: Intragenerational elasticity. Ranking of income 2016-2009

\begin{tabular}{|c|c|c|c|c|c|c|}
\hline & \multicolumn{6}{|c|}{ Percentile of income (final year) } \\
\hline & $2009 / 2016$ & $2009 / 2012$ & $2010 / 2013$ & $2011 / 2014$ & $2012 / 2015$ & $2013 / 2016$ \\
\hline \multirow{2}{*}{ Percentile of income (initial year) } & $0.747^{* * *}$ & $0.836^{* * *}$ & $0.857^{* * *}$ & $0.861^{* * *}$ & $0.873^{* * *}$ & $0.862^{* * *}$ \\
\hline & $(0.000699)$ & $(0.000596)$ & $(0.000547)$ & $(0.000550)$ & $(0.000535)$ & $(0.000532)$ \\
\hline Observations & $1,040,140$ & $1,040,140$ & $1,040,140$ & $1,040,140$ & $1,040,140$ & $1,040,140$ \\
\hline R-squared & 0.611 & 0.739 & 0.773 & 0.777 & 0.783 & 0.769 \\
\hline \multicolumn{7}{|c|}{ Women } \\
\hline \multirow[t]{2}{*}{ Percentile of income (initial year) } & $0.763^{* * *}$ & $0.848^{* * *}$ & $0.871^{* * *}$ & $0.880^{* * *}$ & $0.887^{* * *}$ & $0.874^{* * *}$ \\
\hline & $(0.000925)$ & $(0.000780)$ & $(0.000716)$ & $(0.000708)$ & $(0.000708)$ & $(0.000697)$ \\
\hline Observations & 542,810 & 550,263 & 545,563 & 545,656 & 543,403 & 541,025 \\
\hline R-squared & 0.629 & 0.750 & 0.787 & 0.796 & 0.797 & 0.788 \\
\hline \multicolumn{7}{|c|}{ Men } \\
\hline \multirow[t]{2}{*}{ Percentile of income (initial year) } & $0.737^{* * *}$ & $0.826^{* * *}$ & $0.851^{* * *}$ & $0.849^{* * *}$ & $0.858^{* * *}$ & $0.846^{* * *}$ \\
\hline & $(0.00105)$ & $(0.000910)$ & $(0.000837)$ & $(0.000854)$ & $(0.000818)$ & $(0.000791)$ \\
\hline Observations & 495,587 & 489,181 & 482,111 & 483,585 & 479,467 & 477,069 \\
\hline R-squared & 0.581 & 0.704 & 0.743 & 0.742 & 0.754 & 0.746 \\
\hline
\end{tabular}

Note. Own calculations based on tax records (DGI). Coefficients of income rank in end year against income rank base year (with sex, age groups and a dummy for capital income receivers as covariates). In each column, a different set of base/end year is presented. The first panel refers to the whole population, the second restricts the sample to women and the last, to men.

Robust standard errors in parentheses ${ }^{* * *} \mathrm{p}<0.01,{ }^{* *} \mathrm{p}<0.05,{ }^{*} \mathrm{p}<0.1$

Table A.15: Income mobility indices, 2009-2016

\begin{tabular}{|c|c|c|c|c|c|}
\hline & Total income & Labor income & Mixed income & Capital income & Pensions \\
\hline & \multicolumn{5}{|c|}{ All } \\
\hline$\overline{\text { Atkinson mobility ratio }}$ & 0,35 & 0,42 & 0,41 & 0,63 & 0,20 \\
\hline Determinant index & 0,82 & 0,89 & 0,89 & 0,93 & 0,54 \\
\hline Shorrocks' MET - Prais & 0,75 & 0,80 & 0,82 & 0,98 & 0,52 \\
\hline \multirow[t]{2}{*}{ Average jump } & 1,54 & 1,79 & 1,71 & 2,46 & 0,97 \\
\hline & \multicolumn{5}{|c|}{ Men } \\
\hline$\overline{\text { Atkinson mobility ratio }}$ & 0,39 & 0,45 & 0,41 & 0,60 & 0,23 \\
\hline Determinant index & 0,83 & 0,91 & 0,89 & 0,91 & 0,59 \\
\hline Shorrocks' MET - Prais & 0,78 & 0,81 & 0,82 & 0,97 & 0,54 \\
\hline \multirow[t]{2}{*}{ Average jump } & 1,72 & 1,90 & 1,74 & 2,34 & 0,99 \\
\hline & \multicolumn{5}{|c|}{ Women } \\
\hline Atkinson inmobility ratio & 0,31 & 0,39 & 0,37 & 0,55 & 0,20 \\
\hline Determinant index & 0,81 & 0,88 & 0,82 & 0,95 & 0,53 \\
\hline Shorrocks' MET - Prais & 0,73 & 0,78 & 0,81 & 0,90 & 0,52 \\
\hline Average jump & 1,39 & 1,65 & 1,54 & 2,41 & 0,97 \\
\hline
\end{tabular}

Note. Own calculations based on tax records (DGI). Standard income (in)mobility indices depicted. First column depicts results for total income, whilst the rest present results for all income sources. 
Table A.16: Transition matrix, women: 2009-2016

\begin{tabular}{l|cccccccccc|cc}
\hline & \multicolumn{10}{|c}{2016} \\
\hline 2009 & Decil 1 & Decil 2 & Decil 3 & Decil 4 & Decil 5 & Decil 6 & Decil 7 & Decil 8 & Decil 9 & Decil 10 & Top 5 & Top 1 \\
\hline Decil 1 & $34.5 \%$ & $18.5 \%$ & $10.5 \%$ & $7.7 \%$ & $7.6 \%$ & $6.7 \%$ & $4.9 \%$ & $3.3 \%$ & $2.2 \%$ & $1.1 \%$ & $2.9 \%$ & $6.0 \%$ \\
Decil 2 & $18.0 \%$ & $31.7 \%$ & $23.0 \%$ & $10.7 \%$ & $6.3 \%$ & $5.1 \%$ & $3.5 \%$ & $2.4 \%$ & $1.4 \%$ & $0.8 \%$ & $1.9 \%$ & $3.8 \%$ \\
Decil 3 & $27.8 \%$ & $36.1 \%$ & $16.7 \%$ & $7.2 \%$ & $4.8 \%$ & $3.7 \%$ & $2.5 \%$ & $1.7 \%$ & $1.0 \%$ & $0.5 \%$ & $1.4 \%$ & $2.9 \%$ \\
Decil 4 & $6.0 \%$ & $5.6 \%$ & $34.8 \%$ & $20.2 \%$ & $13.8 \%$ & $7.7 \%$ & $5.1 \%$ & $3.7 \%$ & $1.9 \%$ & $1.1 \%$ & $2.5 \%$ & $4.8 \%$ \\
Decil 5 & $5.0 \%$ & $3.8 \%$ & $5.3 \%$ & $39.3 \%$ & $19.5 \%$ & $11.4 \%$ & $7.4 \%$ & $4.4 \%$ & $2.6 \%$ & $1.3 \%$ & $2.6 \%$ & $5.2 \%$ \\
Decil 6 & $3.4 \%$ & $2.5 \%$ & $4.5 \%$ & $5.8 \%$ & $33.9 \%$ & $23.0 \%$ & $12.0 \%$ & $8.1 \%$ & $4.5 \%$ & $1.9 \%$ & $3.6 \%$ & $6.8 \%$ \\
Decil 7 & $2.1 \%$ & $1.0 \%$ & $3.0 \%$ & $4.7 \%$ & $6.1 \%$ & $29.3 \%$ & $27.2 \%$ & $14.2 \%$ & $9.0 \%$ & $3.0 \%$ & $4.0 \%$ & $6.9 \%$ \\
Decil 8 & $1.4 \%$ & $0.4 \%$ & $1.1 \%$ & $3.0 \%$ & $4.9 \%$ & $6.8 \%$ & $25.8 \%$ & $32.0 \%$ & $18.3 \%$ & $6.1 \%$ & $4.9 \%$ & $6.6 \%$ \\
Decil 9 & $0.9 \%$ & $0.2 \%$ & $0.5 \%$ & $0.9 \%$ & $2.5 \%$ & $5.0 \%$ & $8.1 \%$ & $22.3 \%$ & $40.7 \%$ & $18.2 \%$ & $9.8 \%$ & $8.8 \%$ \\
Decil 10 & $0.6 \%$ & $0.1 \%$ & $0.3 \%$ & $0.4 \%$ & $0.6 \%$ & $1.4 \%$ & $3.2 \%$ & $7.7 \%$ & $18.2 \%$ & $65.8 \%$ & $63.8 \%$ & $42.1 \%$ \\
\hline Top 5 & $0.7 \%$ & $0.1 \%$ & $0.2 \%$ & $0.3 \%$ & $0.3 \%$ & $0.5 \%$ & $0.9 \%$ & $2.7 \%$ & $4.5 \%$ & $40.3 \%$ & $52.5 \%$ & $41.9 \%$ \\
Top 1 & $0.4 \%$ & $0.1 \%$ & $0.1 \%$ & $0.1 \%$ & $0.1 \%$ & $0.2 \%$ & $0.3 \%$ & $0.4 \%$ & $0.6 \%$ & $8.9 \%$ & $15.4 \%$ & $26.9 \%$ \\
\hline
\end{tabular}

Note. Own calculations based on tax records (DGI). In each cell, the percentage of individuals that were located in a given income group in 2009 (rows) and were part of an income group in 2016 (columns) is depicted. Income groups for both years are the ten deciles of total income, top $5 \%$ and top $1 \%$.

Table A.17: Transition matrix, men: 2009-2016

\begin{tabular}{l|cccccccccccc}
\hline & \multicolumn{10}{c}{2016} \\
\hline 2009 & Decil 1 & Decil 2 & Decil 3 & Decil 4 & Decil 5 & Decil 6 & Decil 7 & Decil 8 & Decil 9 & Decil 10 & Top 5 & Top 1 \\
\hline Decil 1 & $26.3 \%$ & $24.8 \%$ & $10.5 \%$ & $9.8 \%$ & $8.7 \%$ & $6.5 \%$ & $4.9 \%$ & $3.8 \%$ & $2.4 \%$ & $1.2 \%$ & $4.8 \%$ & $9.7 \%$ \\
Decil 2 & $43.0 \%$ & $31.8 \%$ & $7.2 \%$ & $5.1 \%$ & $4.0 \%$ & $2.9 \%$ & $2.1 \%$ & $1.7 \%$ & $1.0 \%$ & $0.5 \%$ & $1.7 \%$ & $3.3 \%$ \\
Decil 3 & $9.8 \%$ & $23.0 \%$ & $30.6 \%$ & $12.2 \%$ & $8.5 \%$ & $6.2 \%$ & $4.6 \%$ & $3.4 \%$ & $2.2 \%$ & $1.0 \%$ & $3.0 \%$ & $5.9 \%$ \\
Decil 4 & $7.5 \%$ & $7.1 \%$ & $25.7 \%$ & $23.0 \%$ & $13.2 \%$ & $8.8 \%$ & $6.4 \%$ & $4.7 \%$ & $2.7 \%$ & $1.2 \%$ & $2.9 \%$ & $5.5 \%$ \\
Decil 5 & $4.8 \%$ & $5.6 \%$ & $8.9 \%$ & $26.8 \%$ & $19.2 \%$ & $13.0 \%$ & $9.4 \%$ & $6.6 \%$ & $4.2 \%$ & $1.6 \%$ & $3.4 \%$ & $6.3 \%$ \\
Decil 6 & $3.0 \%$ & $3.7 \%$ & $7.5 \%$ & $8.6 \%$ & $26.4 \%$ & $19.8 \%$ & $14.5 \%$ & $9.5 \%$ & $5.3 \%$ & $1.9 \%$ & $3.3 \%$ & $5.5 \%$ \\
Decil 7 & $2.0 \%$ & $1.8 \%$ & $5.1 \%$ & $6.4 \%$ & $8.3 \%$ & $26.2 \%$ & $23.8 \%$ & $15.1 \%$ & $8.8 \%$ & $2.8 \%$ & $3.7 \%$ & $5.8 \%$ \\
Decil 8 & $1.5 \%$ & $1.1 \%$ & $2.5 \%$ & $5.2 \%$ & $6.1 \%$ & $8.3 \%$ & $23.1 \%$ & $29.7 \%$ & $17.3 \%$ & $5.2 \%$ & $4.9 \%$ & $7.2 \%$ \\
Decil 9 & $1.0 \%$ & $0.6 \%$ & $1.2 \%$ & $2.1 \%$ & $4.4 \%$ & $6.5 \%$ & $8.1 \%$ & $18.6 \%$ & $41.2 \%$ & $15.8 \%$ & $8.9 \%$ & $8.9 \%$ \\
Decil 10 & $0.8 \%$ & $0.4 \%$ & $0.6 \%$ & $0.8 \%$ & $1.1 \%$ & $1.7 \%$ & $3.0 \%$ & $6.8 \%$ & $14.6 \%$ & $68.3 \%$ & $62.0 \%$ & $38.9 \%$ \\
\hline Top 5 & $0.6 \%$ & $0.3 \%$ & $0.4 \%$ & $0.5 \%$ & $0.5 \%$ & $0.7 \%$ & $0.9 \%$ & $2.6 \%$ & $3.6 \%$ & $40.1 \%$ & $50.0 \%$ & $35.4 \%$ \\
Top 1 & $0.3 \%$ & $0.2 \%$ & $0.1 \%$ & $0.2 \%$ & $0.2 \%$ & $0.2 \%$ & $0.3 \%$ & $0.5 \%$ & $0.6 \%$ & $8.3 \%$ & $12.8 \%$ & $21.6 \%$ \\
\hline
\end{tabular}

Note. Own calculations based on tax records (DGI). In each cell, the percentage of individuals that were located in a given income group in 2009 (rows) and were part of an income group in 2016 (columns) is depicted. Income groups for both years are the ten deciles of total income, top $5 \%$ and top $1 \%$. 
Table A.18: Transition matrix, 2009-2013

\begin{tabular}{l|rrrrrrrrrr|rr}
\hline & \multicolumn{10}{|c}{2013} \\
\hline 2009 & Decil 1 & Decil 2 & Decil 3 & Decil 4 & Decil 5 & Decil 6 & Decil 7 & Decil 8 & Decil 9 & Decil 10 & Top 5 & Top 1 \\
\hline Decil 1 & $51.1 \%$ & $11.8 \%$ & $10.4 \%$ & $9.8 \%$ & $8.0 \%$ & $5.9 \%$ & $4.0 \%$ & $2.6 \%$ & $1.5 \%$ & $0.7 \%$ & $0.5 \%$ & $0.6 \%$ \\
Decil 2 & $29.8 \%$ & $50.9 \%$ & $7.6 \%$ & $5.8 \%$ & $4.2 \%$ & $2.9 \%$ & $2.0 \%$ & $1.2 \%$ & $0.8 \%$ & $0.3 \%$ & $0.2 \%$ & $0.2 \%$ \\
Decil 3 & $5.6 \%$ & $29.0 \%$ & $28.1 \%$ & $9.3 \%$ & $6.1 \%$ & $4.2 \%$ & $3.0 \%$ & $1.9 \%$ & $1.1 \%$ & $0.5 \%$ & $0.3 \%$ & $0.4 \%$ \\
Decil 4 & $4.9 \%$ & $3.2 \%$ & $39.8 \%$ & $24.5 \%$ & $11.3 \%$ & $6.8 \%$ & $4.3 \%$ & $2.8 \%$ & $1.6 \%$ & $0.7 \%$ & $0.5 \%$ & $0.5 \%$ \\
Decil 5 & $3.6 \%$ & $2.3 \%$ & $5.7 \%$ & $37.1 \%$ & $24.6 \%$ & $11.9 \%$ & $7.1 \%$ & $4.3 \%$ & $2.4 \%$ & $1.0 \%$ & $0.7 \%$ & $1.0 \%$ \\
Decil 6 & $2.1 \%$ & $1.5 \%$ & $4.1 \%$ & $6.3 \%$ & $33.4 \%$ & $26.2 \%$ & $13.4 \%$ & $7.8 \%$ & $3.9 \%$ & $1.3 \%$ & $1.0 \%$ & $1.1 \%$ \\
Decil 7 & $1.2 \%$ & $0.6 \%$ & $2.4 \%$ & $3.7 \%$ & $6.2 \%$ & $31.1 \%$ & $31.2 \%$ & $14.5 \%$ & $7.0 \%$ & $2.0 \%$ & $1.3 \%$ & $1.3 \%$ \\
Decil 8 & $0.8 \%$ & $0.4 \%$ & $1.1 \%$ & $2.2 \%$ & $3.7 \%$ & $6.4 \%$ & $26.8 \%$ & $38.1 \%$ & $16.4 \%$ & $4.1 \%$ & $2.2 \%$ & $1.6 \%$ \\
Decil 9 & $0.5 \%$ & $0.2 \%$ & $0.4 \%$ & $0.8 \%$ & $1.8 \%$ & $3.4 \%$ & $6.3 \%$ & $22.3 \%$ & $49.9 \%$ & $14.3 \%$ & $6.0 \%$ & $3.0 \%$ \\
Decil 10 & $0.5 \%$ & $0.2 \%$ & $0.3 \%$ & $0.5 \%$ & $0.6 \%$ & $1.0 \%$ & $1.9 \%$ & $4.4 \%$ & $15.4 \%$ & $75.2 \%$ & $87.4 \%$ & $90.4 \%$ \\
\hline Top 5 & $0.3 \%$ & $0.1 \%$ & $0.2 \%$ & $0.2 \%$ & $0.3 \%$ & $0.3 \%$ & $0.5 \%$ & $1.4 \%$ & $2.3 \%$ & $44.4 \%$ & $73.2 \%$ & $86.3 \%$ \\
Top 1 & $0.1 \%$ & $0.0 \%$ & $0.1 \%$ & $0.0 \%$ & $0.1 \%$ & $0.1 \%$ & $0.1 \%$ & $0.2 \%$ & $0.3 \%$ & $9.0 \%$ & $17.1 \%$ & $63.4 \%$ \\
\hline
\end{tabular}

Note. Own calculations based on tax records (DGI). In each cell, the percentage of individuals that were located in a given income group in 2009 (rows) and were part of an income group in 2013 (columns) is depicted. Income groups for both years are the ten deciles of total income, top $5 \%$ and top $1 \%$.

Table A.19: Transition matrix: 2013-2016

\begin{tabular}{l|rrrrrrrrrr|rr}
\hline & \multicolumn{10}{|c}{2016} \\
\hline 2013 & Decil 1 & Decil 2 & Decil 3 & Decil 4 & Decil 5 & Decil 6 & Decil 7 & Decil 8 & Decil 9 & Decil 10 & Top 5 & Top 1 \\
\hline Decil 1 & $45.2 \%$ & $36.4 \%$ & $6.4 \%$ & $4.8 \%$ & $3.5 \%$ & $2.2 \%$ & $1.3 \%$ & $0.7 \%$ & $0.5 \%$ & $0.5 \%$ & $0.5 \%$ & $0.6 \%$ \\
Decil 2 & $27.7 \%$ & $49.4 \%$ & $7.9 \%$ & $3.1 \%$ & $1.9 \%$ & $1.1 \%$ & $0.6 \%$ & $0.3 \%$ & $0.2 \%$ & $0.1 \%$ & $0.1 \%$ & $0.2 \%$ \\
Decil 3 & $7.8 \%$ & $5.3 \%$ & $66.2 \%$ & $14.8 \%$ & $5.5 \%$ & $2.9 \%$ & $1.6 \%$ & $0.8 \%$ & $0.5 \%$ & $0.3 \%$ & $0.4 \%$ & $0.6 \%$ \\
Decil 4 & $6.3 \%$ & $3.6 \%$ & $7.1 \%$ & $55.7 \%$ & $16.1 \%$ & $5.9 \%$ & $2.8 \%$ & $1.5 \%$ & $0.7 \%$ & $0.4 \%$ & $0.4 \%$ & $0.6 \%$ \\
Decil 5 & $4.5 \%$ & $2.3 \%$ & $4.8 \%$ & $9.6 \%$ & $51.1 \%$ & $16.7 \%$ & $6.3 \%$ & $3.0 \%$ & $1.2 \%$ & $0.6 \%$ & $0.6 \%$ & $0.8 \%$ \\
Decil 6 & $3.1 \%$ & $1.3 \%$ & $3.4 \%$ & $5.1 \%$ & $11.2 \%$ & $49.6 \%$ & $16.8 \%$ & $6.5 \%$ & $2.4 \%$ & $0.8 \%$ & $0.7 \%$ & $1.1 \%$ \\
Decil 7 & $2.1 \%$ & $0.8 \%$ & $2.0 \%$ & $3.3 \%$ & $5.2 \%$ & $12.4 \%$ & $49.7 \%$ & $17.9 \%$ & $5.5 \%$ & $1.2 \%$ & $0.9 \%$ & $1.2 \%$ \\
Decil 8 & $1.6 \%$ & $0.5 \%$ & $1.1 \%$ & $2.0 \%$ & $3.2 \%$ & $5.2 \%$ & $13.9 \%$ & $51.6 \%$ & $18.3 \%$ & $2.6 \%$ & $1.4 \%$ & $1.5 \%$ \\
Decil 9 & $1.0 \%$ & $0.3 \%$ & $0.7 \%$ & $1.0 \%$ & $1.7 \%$ & $3.0 \%$ & $5.3 \%$ & $13.9 \%$ & $59.4 \%$ & $13.6 \%$ & $4.2 \%$ & $2.5 \%$ \\
Decil 10 & $0.8 \%$ & $0.2 \%$ & $0.4 \%$ & $0.6 \%$ & $0.6 \%$ & $1.0 \%$ & $1.8 \%$ & $3.7 \%$ & $11.2 \%$ & $79.7 \%$ & $90.7 \%$ & $90.8 \%$ \\
\hline Top 5 & $0.4 \%$ & $0.1 \%$ & $0.2 \%$ & $0.2 \%$ & $0.2 \%$ & $0.3 \%$ & $0.6 \%$ & $1.2 \%$ & $2.1 \%$ & $44.6 \%$ & $77.3 \%$ & $87.7 \%$ \\
Top 1 & $0.1 \%$ & $0.0 \%$ & $0.0 \%$ & $0.1 \%$ & $0.1 \%$ & $0.1 \%$ & $0.1 \%$ & $0.2 \%$ & $0.3 \%$ & $9.1 \%$ & $17.5 \%$ & $66.9 \%$ \\
\hline
\end{tabular}

Note. Own calculations based on tax records (DGI). In each cell, the percentage of individuals that were located in a given income group in 2013 (rows) and were part of an income group in 2016 (columns) is depicted. Income groups for both years are the ten deciles of total income, top 5\% and top $1 \%$. 
Table A.20: Transition matrix within top 10\%, 2009-2016

\begin{tabular}{|c|c|c|c|c|c|c|c|c|c|c|}
\hline 2009 & $\begin{array}{c}2016 \\
91\end{array}$ & 92 & 93 & 94 & 95 & 96 & 97 & 98 & 99 & 100 \\
\hline 91 & $19.3 \%$ & $16.2 \%$ & $15.3 \%$ & $13.3 \%$ & $10.2 \%$ & $8.1 \%$ & $7.3 \%$ & $4.5 \%$ & $3.5 \%$ & $2.4 \%$ \\
\hline 92 & $21.5 \%$ & $15.3 \%$ & $13.9 \%$ & $12.7 \%$ & $11.1 \%$ & $8.9 \%$ & $5.9 \%$ & $5.1 \%$ & $3.3 \%$ & $2.4 \%$ \\
\hline 93 & $13.4 \%$ & $21.6 \%$ & $14.1 \%$ & $13.3 \%$ & $11.6 \%$ & $8.9 \%$ & $7.1 \%$ & $5.2 \%$ & $3.1 \%$ & $1.7 \%$ \\
\hline 94 & $8.7 \%$ & $12.0 \%$ & $22.0 \%$ & $15.0 \%$ & $12.4 \%$ & $10.4 \%$ & $8.8 \%$ & $5.1 \%$ & $3.5 \%$ & $2.1 \%$ \\
\hline 95 & $5.6 \%$ & $8.2 \%$ & $10.9 \%$ & $21.7 \%$ & $17.9 \%$ & $12.4 \%$ & $9.9 \%$ & $7.0 \%$ & $4.3 \%$ & $2.3 \%$ \\
\hline 96 & $3.0 \%$ & $4.8 \%$ & $6.6 \%$ & $9.6 \%$ & $20.8 \%$ & $22.0 \%$ & $13.8 \%$ & $9.7 \%$ & $6.3 \%$ & $3.5 \%$ \\
\hline 97 & $2.5 \%$ & $2.5 \%$ & $4.1 \%$ & $6.7 \%$ & $9.5 \%$ & $20.9 \%$ & $24.7 \%$ & $15.4 \%$ & $9.5 \%$ & $4.2 \%$ \\
\hline 98 & $1.5 \%$ & $2.2 \%$ & $2.5 \%$ & $3.9 \%$ & $5.2 \%$ & $9.3 \%$ & $21.2 \%$ & $30.1 \%$ & $17.4 \%$ & $6.7 \%$ \\
\hline 99 & $1.2 \%$ & $1.8 \%$ & $1.9 \%$ & $2.5 \%$ & $3.1 \%$ & $5.0 \%$ & $8.1 \%$ & $22.2 \%$ & $37.6 \%$ & $16.7 \%$ \\
\hline 100 & $0.8 \%$ & $1.2 \%$ & $1.6 \%$ & $2.5 \%$ & $2.2 \%$ & $3.3 \%$ & $3.5 \%$ & $5.7 \%$ & $18.2 \%$ & $61.0 \%$ \\
\hline
\end{tabular}

Note. Own calculations based on tax records (DGI). In each cell, the percentage of individuals that were located in a given income group in 2009 (rows) and were part of an income group in 2016 (columns) is depicted. Income groups for both years are the ten centiles of the tenth decile of total income, top $5 \%$ and top $1 \%$.

Table A.21: Income Mobility indices (top 10\%)

\begin{tabular}{l|rrrrrr}
\hline & Total income & Labor income & Employees & Self employed & Capital & Pensions \\
\hline Atkinson inmobility ratio & 0.42 & 0.45 & 0.45 & 0.62 & 0.61 & 0.36 \\
Determinant index & 0.89 & 0.96 & 0.96 & 0.93 & 0.97 & 0.72 \\
Shorrocks' MET - Prais & 0.83 & 0.84 & 0.84 & 0.92 & 0.92 & 0.81 \\
Average jump & 1.76 & 1.78 & 1.78 & 2.63 & 2.50 & 1.49 \\
\hline Atkinson inmobility ratio & 0.42 & 0.45 & 0.43 & 0.62 & 0.61 & 0.36 \\
Determinant index & 0.89 & 0.95 & 0.94 & 0.93 & 0.97 & 0.71 \\
Shorrocks' MET - Prais & 0.82 & 0.84 & 0.84 & 0.92 & 0.92 & 0.79 \\
Average jump & 1.77 & 1.81 & 1.72 & 2.75 & 2.55 & 1.48 \\
\hline Atkinson inmobility ratio & 0.42 & 0.44 & 0.42 & 0.62 & 0.60 & 0.36 \\
Determinant index & 0.88 & 0.93 & 0.93 & 0.86 & 0.95 & 0.77 \\
Shorrocks' MET - Prais & 0.84 & 0.85 & 0.84 & 0.94 & 0.92 & 0.82 \\
Average jump & 1.74 & 1.73 & 1.62 & 2.56 & 2.45 & 1.50 \\
\hline
\end{tabular}

Note. Own elaboration based on tax records (DGI). 
Figure A.1: Per capita GDP, 1986-2016 (2005=100)

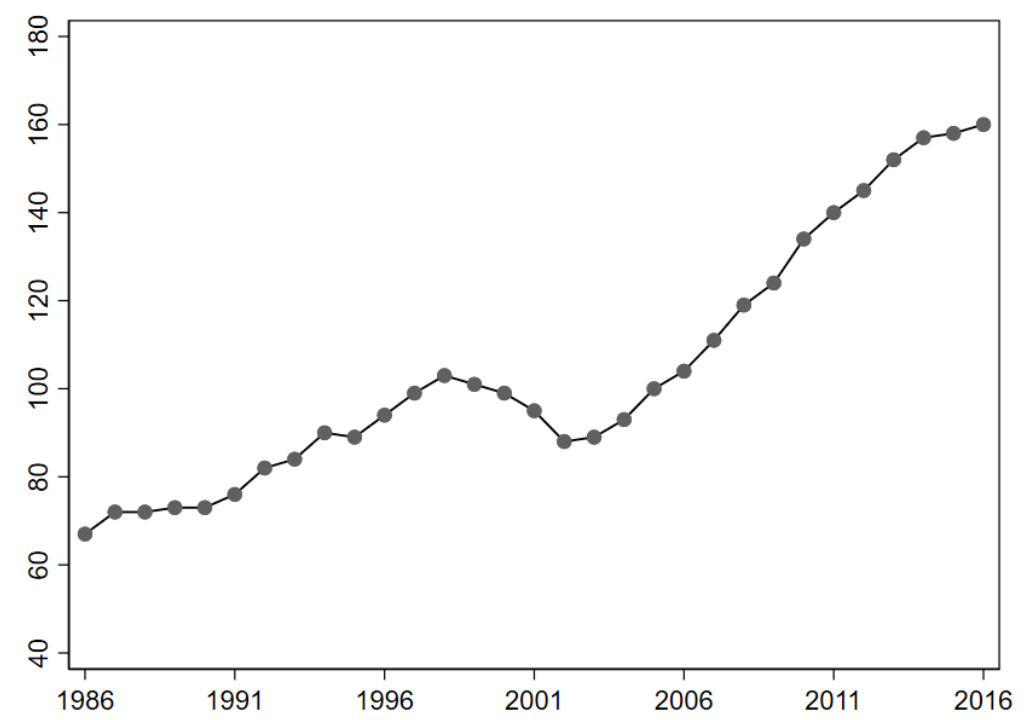

Note. Own calculations based on World Bank data. Base year 2005=100.

Figure A.2: Entry and exit rates by income groups

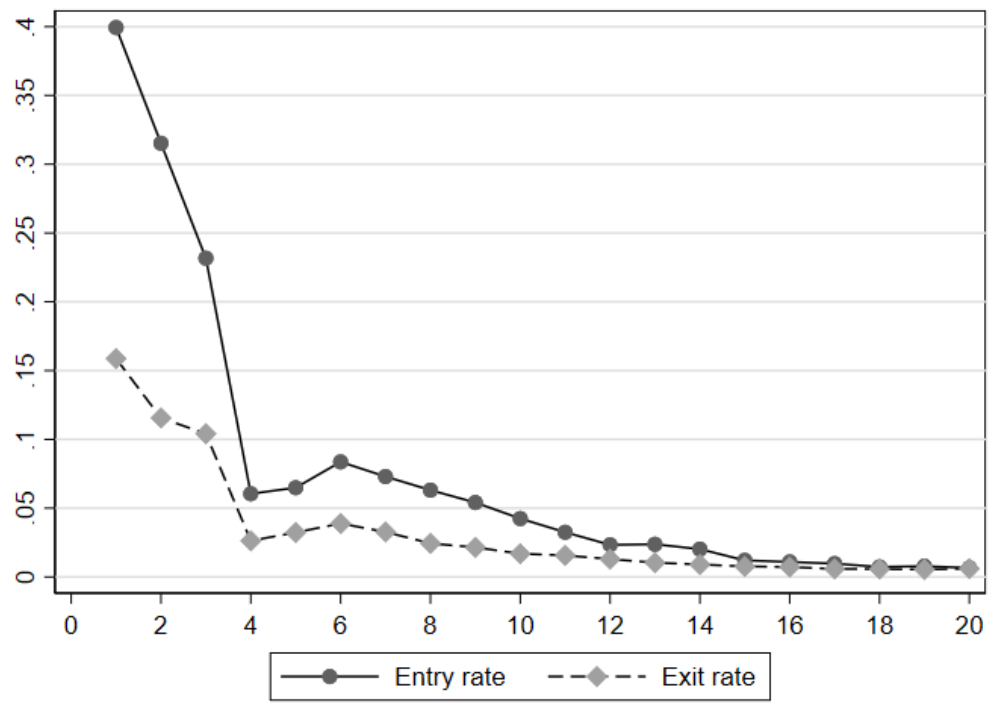

Note. Own calculations based on DGI. Entry and exit rates depicted for 2013; identical results hold for the remaining years. 
Figure A.3: Persistence rate by deciles and centiles of the top $10 \%$
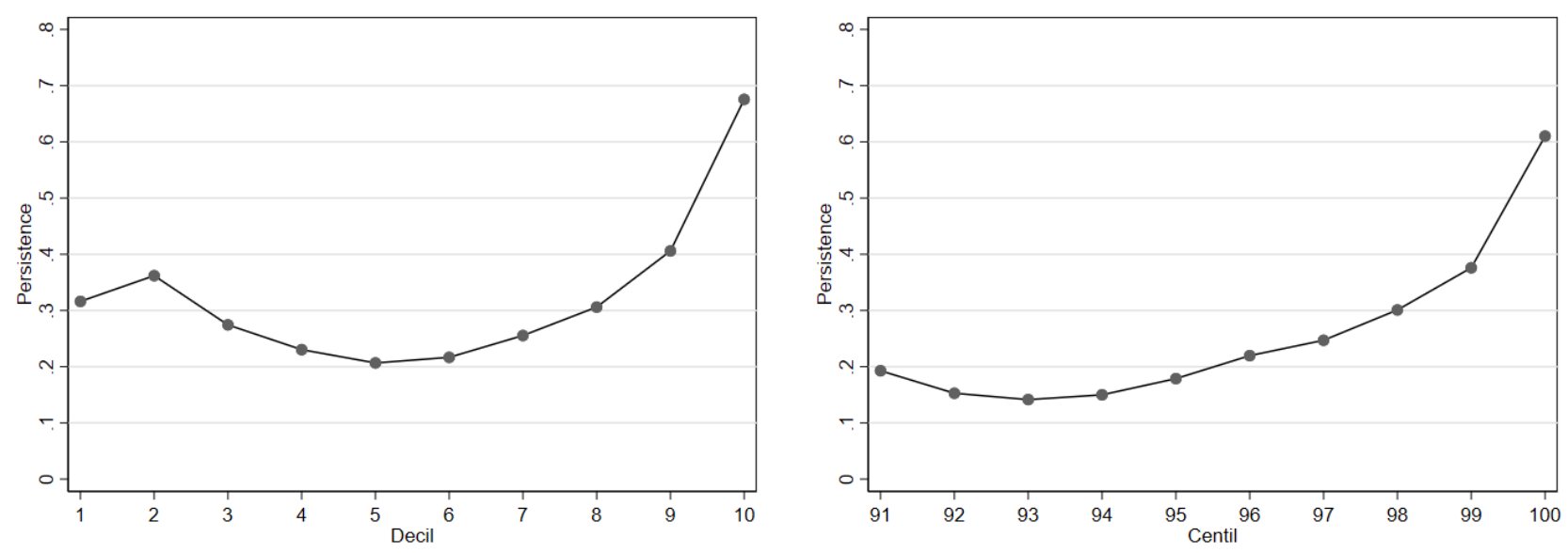

Note. Own elaboration based on tax records (DGI).

Figure A.4: Persistence rates after 1 year by gender (top 1\%)

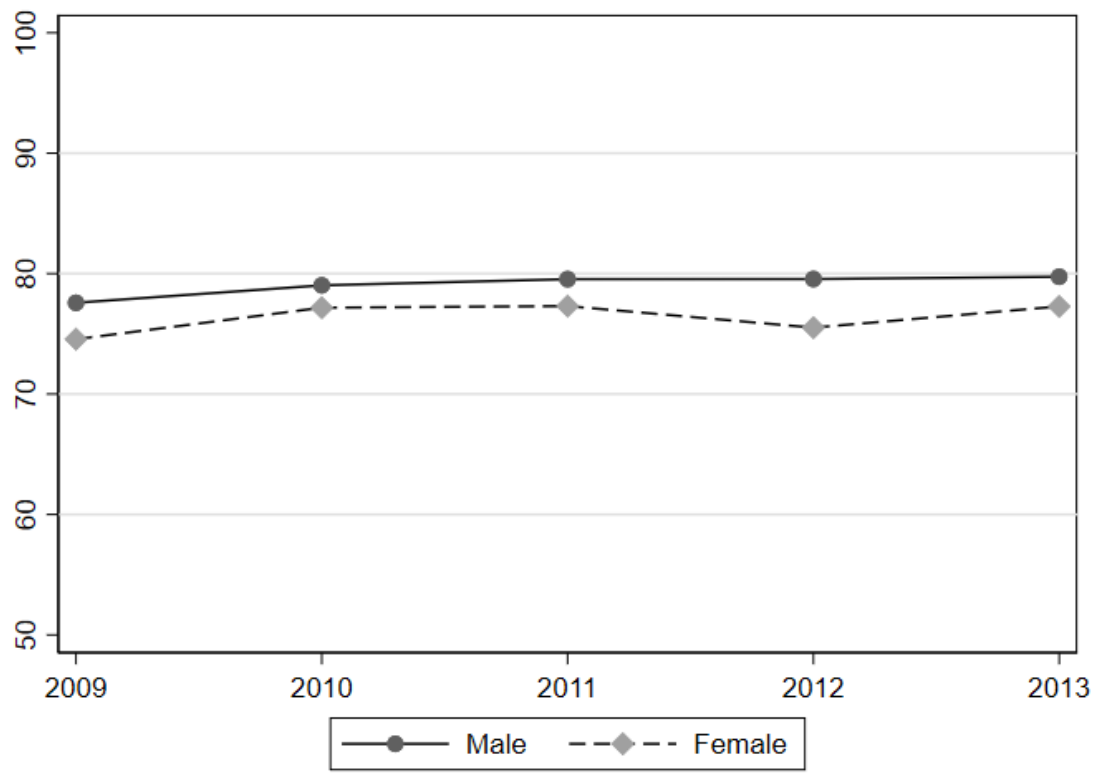

Note. Own calculations based on DGI. Persistence rates after three years is unconditional on fractile membership after one and two years. 
Figure A.5: Fraction of individuals who do not move downwards, 2009-2016.

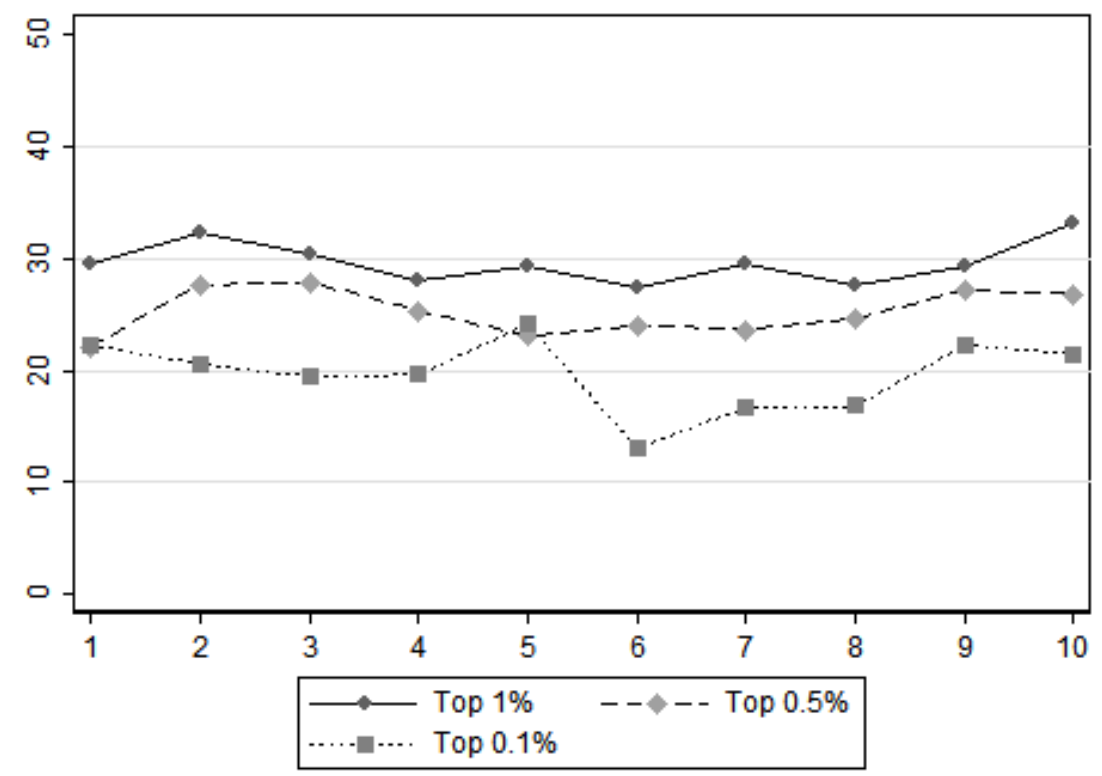

Note. Own calculations based on DGI.Deciles of total income for the Top 1\%, 0.5\% and $0.1 \%$, computed in 2009 and 2016. 